\title{
Photochemistry differs between male and female Juniperus communis L. independently of nutritional availability
}

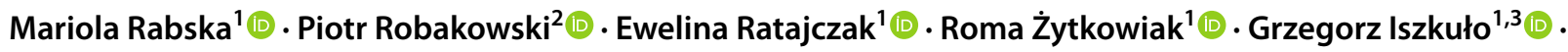 \\ Emilia Pers-Kamczyc ${ }^{1}$ (D)
}

Received: 26 November 2019 / Accepted: 16 June 2020 / Published online: 29 June 2020

(c) The Author(s) 2020

\begin{abstract}
Key message Juniperus communis males are better adapted than females to changing, seasonal environmental conditions due to their higher photosynthetic capacity and the higher concentration of photosynthetic pigments in their needles. Males cope with ROS more efficiently than females having greater carotenoids concentration in needles.

Abstract In dioecious woody plants, females often exhibit greater reproductive effort than male plants and as a result, they can be more vulnerable to different stressors. We hypothesized that female plants of J. communis L. could have a lower photochemical capacity and a higher level of antioxidant enzyme activity and that these differences between males and females would be more pronounced under conditions where nutrient availability is limited. We also assume that additional stressors connected with different seasons would increase those differences. Male and female plants of J. communis growing in fertilized or non-fertilized soils were used to test this hypothesis. The effect of fertilization and sex on photochemical parameters derived from chlorophyll $a$ fluorescence light curves, and on the concentrations of photosynthetic pigments in needles, was determined in different seasons within 2 years. To assess the tolerance of male and female plants to the nutrient deficit, antioxidant enzyme activity, and the level of reactive oxygen species (ROS) were determined. Results revealed sex-related differences in photochemical parameters, level of antioxidant enzyme activity, $\mathrm{H}_{2} \mathrm{O}_{2}$ levels, the concentration of photosynthetic pigments, and in the leaf mass-to-area ratio. This indicates that J. communis males could be better adapted than females to changing, seasonal environmental conditions due to their higher photosynthetic capacity, as reflected by their higher $\mathrm{ETR}_{\max }$, and a higher concentration of photosynthetic pigments in their needles. The sex-related differences concerning photosynthetic capacity and stress response found in our study are constitutive traits of each sex and are genetically based as they occurred independently of fertilization.
\end{abstract}

Keywords Dioecious plants $\cdot$ Chlorophyll $a$ fluorescence $\cdot$ Nutrient stress $\cdot$ Photosynthetic pigments $\cdot$ Antioxidants

$\begin{array}{ll}\text { Abbreviations } \\ \text { ETR } & \text { Apparent electron transport rate }\left(\mu \mathrm{mol} \mathrm{m}{ }^{-2} \mathrm{~s}^{-1}\right) \\ \mathrm{ETR}_{\max } & \text { Maximum value of ETR } \\ F_{\mathrm{v}} / F_{\mathrm{m}} & \begin{array}{l}\text { Maximum quantum yield of photosystem II } \\ \text { photochemistry }\end{array} \\ F_{\mathrm{m}} & \text { Maximum fluorescence yield } \\ F_{\mathrm{m}}^{\prime} & \text { Maximum fluorescence in the light }\end{array}$

Communicated by Porth.

Electronic supplementary material The online version of this article (https://doi.org/10.1007/s00468-020-02004-8) contains supplementary material, which is available to authorized users.

Emilia Pers-Kamczyc

epk@man.poznan.pl

Extended author information available on the last page of the article
$F_{0} \quad$ Minimum fluorescence yield

$F_{\text {s }} \quad$ Steady-state fluorescence

NPQ Non-photochemical quenching of fluorescence

PPF Photosynthetic photon flux ( $\left.\mu \mathrm{mol} \mathrm{m} \mathrm{m}^{-2} \mathrm{~s}^{-1}\right)$

$\mathrm{PPF}_{\text {sat }} \quad$ Saturating level of photosynthetic photon flux

PSII Photosystem II

$\Phi_{\text {PSII }} \quad$ Quantum yield of PSII photochemistry

$\Phi_{\mathrm{PPF}_{\text {sat }}} \quad$ Quantum yield of PSII photochemistry at the saturation level of PPF

SOD Superoxide dismutase

POX Guaiacol peroxidase

CAT Catalase

APX Ascorbate peroxidase 


\section{Introduction}

Dioecious species of plants form male and female flowers on separate individuals. Due to their different reproductive roles, sexes vary not only in the structural units they produce but also have differences in their morphology, physiology, and in their response to environmental conditions. The differences between sexes can be reflected by variations in growth (Lloyd and Webb 1977; Allen and Antos 1993; Obeso et al. 1998; Iszkuło and Boratyński 2011; Huang et al. 2018), the morphology of individual structures (Leigh and Nicotra 2003; Delph et al. 2011), physiology (Dawson and Bliss 1989; Obeso et al. 1998; Robakowski et al. 2018) as well as gene expression in flowers tissue (Sanderson et al. 2019).

Female plants of dioecious woody species often exhibit a greater reproductive effort than male plants (Obeso 2002; Montesinos et al. 2006) and require more favourable habitats to survive (Chen et al. 2015; Song et al. 2018). However, assessing reproductive investments in different genders is not an obvious task and recent studies revealed that measurements based on biomass may be less informative than those based on costs of nutrient and construction of the reproductive tissue (Lei et al. 2017b). Female plants have the potential to compensate costs associated with greater reproductive effort through increasing stomatal density, leaf area and gas exchange per unit leaf area as well as different strategies for $\mathrm{N}$ storage (Wallace and Rundel 1979; Kohorn 1994; Meagher 1999; Obeso 2002; Iszkuło et al. 2009; Montesinos et al. 2012; Iszkuło et al. 2013; Nowak-Dyjeta et al. 2017).

Dioecy is often associated with spatial segregation of male and female individuals, in particular a sex-related preference to inhabit specific types of microhabitats (Freeman et al. 1976; Hultine et al. 2016) and can result in a biased sex ratio (Field et al. 2013), especially within nutrient stress conditions (Song et al. 2018). Such a separation helps to limit intraspecific and cross-sex competition, which can influence the fitness of at least one sex (Chen et al. 2014).

Minerals greatly influence plant growth and different levels of species-specific tolerance to nutrient levels do exist (Laliberté et al. 2012), which can be observed by different nutrient requirements and tolerance to different soil N:P ratios (Güsewell and Koerselman 2002; Güsewell and Bollens 2003). The concentration of nutrients in plant tissues differ depending on environmental conditions and species (Kutbay and Ok 2003; Schmidt et al. 2010; Sardans et al. 2012) as well as leaf age (Miller et al. 1990) and can have a significant impact on many different biochemical processes (Pozo et al. 1999; Hermans et al. 2006; Ren et al. 2010). Plants have evolved mechanisms that allow them to adapt to and survive limited nutritional environments by altering their metabolism and allocation of biomass (Hermans et al. 2006; Rouached et al. 2010); however, fertilized plants can generally cope more readily with various stresses than plants with limited access to resources (Starck et al. 2000). Notably, when several stresses are exerted together, negative impacts on plant physiology increase, and plant survival is more threatened (Holopainen and Gershenzon 2010).

Stress related with nutrient availability can alter the process of the photosynthesis as well as the production of the reactive oxygen species (ROS). Photosynthetic capacity and efficiency can be indirectly determined by measuring chlorophyll $a$ fluorescence (Retuerto et al. 2006; Simancas et al. 2016). A decline in photosynthesis, defined as photoinhibition, is observed when plant is exposed to stressors (Adams et al. 2004) and can be assessed by measuring maximum quantum yield of photosystem II (PSII) photochemistry $\left(F_{\mathrm{v}} / F_{\mathrm{m}}\right) . F_{\mathrm{v}} / F_{\mathrm{m}}$ values lower than 0.8 are considered as a good indicator of photoinhibition (Björkman and Demmig 1987; Lüttge et al. 2003). Plants protect themselves from photoinhibition increasing losses of excessive energy as heat by non-photochemical quenching of fluorescence (NPQ) (Maxwell and Johnson 2000; Szabó et al. 2005; Kromdijk et al. 2016). We assume that NPQ can be higher in female plants, which often have greater costs of reproduction and are more sensitive to stress injury (He et al. 2016). Numerous studies, however, have reported no sex differences in NPQ values (de la Bandera et al. 2008; Ait Said et al. 2013).

Reactive oxygen species (ROS), which regulate the redox state and function as regulators of energy and metabolic fluxes, are generated during photosynthesis (Foyer 2018). Maintaining antioxidant systems that regulate ROS levels in cells is vitally important for maintaining high photosynthetic rates as ROS are capable of damaging electron transport chain structures. ROS, however, can also function as signalling molecules in plants (Foyer and Shigeoka 2011). Plants produce antioxidant enzymes, such as catalase (CAT) and ascorbate peroxidases (APX) that scavenge hydrogen peroxide, as well as superoxide dismutase (SOD) which scavenges superoxide. In response to stress conditions, the activity of these enzymes tends to increase more sharply in female than in male individuals (Gupta et al. 2012; He et al. 2016), but not always (Lu et al. 2014). An increase in SOD and APX activity can be induced by insufficient nitrogen, phosphorus, and potassium (Tewari et al. 2007) and nutrient limitation can impact the internal structures of cells and the concentration of photosynthetic pigments (Tewari et al. 2007). Other stresses can also induce changes in antioxidant enzyme activity (Alguacil et al. 2006) and the degree of alteration can differ between male and female (Zhang et al. 2010).

In the present study, the effect of long-term nutrition limitation on the photosynthetic apparatus and antioxidant 
system in male and female plants of common juniper (Juniperus communis L.) was investigated. Juniperus communis is a dioecious, evergreen shrub or small tree and is described as a pioneer species that plays an important role in natural forest succession (Thomas et al. 2007). It naturally occurs in cool, temperate areas of the Northern Hemisphere; including Asia, Europe, and North America (Adams et al. 2003). Despite its wide range, decreases in the population of this species have been occurring in Europe (Oostermeijer and De Knegt 2004; Verheyen et al. 2009). A male-biased sex ratio is also observed in many populations of this species, which may be related to stress conditions as more male than female individuals occur in sites with limited water availability (Ortiz et al. 2002). After reaching maturity, male plants have a greater radial growth rate (Iszkuło and Boratyński 2011) and smaller needle area (Nowak-Dyjeta et al. 2017) than female plants.

We hypothesized that male and female J. communis plants would exhibit constitutive differences in several physiological parameters and those differences would be more pronounced in nutrient limited environment.

\section{Materials and methods}

\section{Plant material}

The study was conducted at the Institute of Dendrology, Polish Academy of Sciences in Kórnik, Poland. Shoots of $J$. communis L. were rooted in 2012. Specifically, fifty shoots were collected from each of the ten male $(\widehat{\delta})$ and ten female () mature plants growing in the Rokita forest district, Western Pomerania, Poland. Cuttings of a similar size of about $10 \mathrm{~cm}$ were taken from the middle part of each crown, growing in similar light conditions. In total, 1000 shoots were rooted and kept in a greenhouse in $10 \mathrm{~L}$ pots in which they were grown till the end of the experiment. They were placed under 2-m-high scaffolding that was covered with a shading net (reducing full sunlight by $50 \%$ ). The relative photosynthetic photon flux density inside the shaded canopy was measured using a line quantum sensor (Apogee Inc.) according to the method of Messier and Puttonen (1995). The soil substrate used in the experiment was taken from a mixed broadleaved forest and $10 \%$ of the total soil volume originated from the location in which the maternal plants grew to introduce mycorrhizae.

\section{Experimental design and sampling}

In March 2013, all seedlings were randomly divided into two blocks containing both genders, and then within each block, two fertilization groups were established. Half of the seedlings were fertilized and plants were described as fertilized plants $(\mathrm{F})$, whereas the remaining plants were grown without any fertilizer and were described as non-fertilized plants (NF). Plants from the same paternal or maternal origin were present in both treatment groups with the same number of individuals in each group. Since 2013, F plants were fertilized every year after flowering in May. The fertilizer consisted of 6 grams of slow-release fertilizer $(15.0 \% \mathrm{~N}, 9.0 \% \mathrm{P}$, $12.0 \% \mathrm{~K}, 2.5 \% \mathrm{MgO}$ and microelements, Osmocote Exact, ICL, Israel) per liter. Plants in the NF group were grown without any fertilizer. Pots were placed at the same distance of $30 \mathrm{~cm}$ to avoid density effects. Each plant was irrigated separately with an automatic drop irrigation system. As fertilization increases the growth of plants and it is related to water availability, plants from both groups were irrigated with different water doses. Fertilized plants were irrigated twice more than nonfertilized plants to keep the medium soil moisture during the whole vegetation season.

Measurements were conducted during two following years and 1 year needles were sampled four times per year (May, July, October, January) during 2015 and 2016. Sampling dates were linked to plant phenology with the flowering beginning in May, the most intensive plant growth occurring in July, biomass allocation primarily to roots in September/October, and a period of dormancy in January. Needles were collected from three similarly shaded branches, located one-third of the way below the top of plants. At each sampling point, 1 year needles from 32 seedlings were used for all analysis ( 4 seedlings $\times 2$ fertilization treatments $\times 2$ sexes $\times 2$ blocks). Seedlings were randomly chosen; however, seedlings from the same genotype were analyzed from both treatment groups to reduce the impact of genotype on the investigated physiological traits.

\section{Microclimate}

Temperature and humidity were monitored by four ELUSB-2 + data loggers (EasyLog, Inc.) placed near the top of plants. Meteorological parameters were measured every hour over the 2 year duration of the study. Monthly mean, minimal, and maximal temperatures, as well as monthly mean relative humidity values, occurring over the sampling period are presented in Table 1. Monthly mean temperatures varied between $20.3{ }^{\circ} \mathrm{C} \pm 7.9^{\circ} \mathrm{C}$ (mean \pm SE) in July, 2016 and $-0.7{ }^{\circ} \mathrm{C} \pm 4.6^{\circ} \mathrm{C}$ in January, 2017. The highest temperature occurred in July, 2015 and the lowest in January, 2016. The difference between the highest and lowest temperature over the course of the entire study was $60.5^{\circ} \mathrm{C}$. The lowest relative humidity occurred at the beginning of the experiment in May, $2015\left(\mathrm{RH}_{\min }=65.0 \pm 23.6\right)$ and the highest was observed at the end of the experiment, in January, $2017\left(\mathrm{RH}_{\max }=100.0 \pm 7.5\right)$. The difference between 
Table 1 Air temperature and relative humidity monitored over the course of the 2-year study

\begin{tabular}{llllll}
\hline Dates & & \multicolumn{2}{l}{ Monthly temperature $\left({ }^{\circ} \mathrm{C}\right)$} & \begin{tabular}{l} 
Relative air \\
humidity \\
\cline { 3 - 5 }
\end{tabular} \\
\cline { 3 - 5 } I Year & May 2015 & $12.8 \pm 8.7$ & -2.5 & 35.5 & $65.0 \pm 23.6$ \\
& July 2015 & $18.9 \pm 8.4$ & 4.0 & 45.0 & $71.4 \pm 22.9$ \\
& October & $13.0 \pm 7.8$ & -2.0 & 38.0 & $73.8 \pm 19.2$ \\
2015 & & & & \\
& January & $1.0 \pm 7.0$ & -15.5 & 14.5 & $92.4 \pm 8.2$ \\
2016 & & & & \\
II Year & May 2016 & $11.4 \pm 8.3$ & -3.5 & 36.0 & $69.6 \pm 23.8$ \\
& July 2016 & $20.3 \pm 7.9$ & 4.5 & 44.5 & $72.7 \pm 23.4$ \\
& October & $14.3 \pm 7.9$ & 0.0 & 40.0 & $78.8 \pm 21.3$ \\
2016 & & & & \\
& January & $-0.7 \pm 4.6$ & -15.0 & 10.5 & $100.0 \pm 7.5$ \\
2017 & & & & \\
\hline
\end{tabular}

Data were registered hourly near plants of J. communis. Mean monthly, minimum and maximum temperatures and mean monthly values of relative humidity are presented (means with standard errors, $n=744$ )

the lowest and the highest mean relative humidity over the course of the study was $35.6 \%$.

\section{Determination of enzyme activity and the level of reactive oxygen species (ROS)}

The activity of ascorbate peroxidase (APX, EC.1.11.1.11), superoxide dismutase (SOD, EC. 1.15.11), guaiacol peroxidase (GP, EC. 1.11.1.7), and catalase (CAT, EC 1.11.1.6) in the cytosolic fraction of needle samples was determined. ROS [superoxide $\left(\mathrm{O}_{2}^{-}\right)$and hydrogen peroxide $\left.\left(\mathrm{H}_{2} \mathrm{O}_{2}\right)\right]$ levels were also measured.

All enzyme assays were performed on samples of whole, 1 year needles and the same crude extract was used to determine the activity for all of the measured enzymes. All extraction procedures were carried out at $4{ }^{\circ} \mathrm{C}$. Samples were ground in liquid nitrogen and extracted for $1 \mathrm{~h}$ in $50 \mathrm{mM}$ sodium phosphate buffer $(\mathrm{pH}$ 7.0) containing $0.2 \mathrm{mM}$ EDTA and $20 \%$ polyvinylpolypyrrolidone. Homogenates were filtered through two layers of cheesecloth and were subsequently centrifuged at $4{ }^{\circ} \mathrm{C}$ at $20,000 \mathrm{~g}$ for $20 \mathrm{~min}$. The supernatants were used to determine enzyme activity assays after they were desalted on a Sephadex G25 (Sigma-Aldrich) standard column as described by Helmerhorst and Stockes (1980).

APX activity was measured according to Nakano and Asada (1981) and was based on the decrease in absorbance at $290 \mathrm{~nm}$ due to ascorbic acid (ASA) oxidation for 5-10 min. The first step of the reaction included the addition of $\mathrm{H}_{2} \mathrm{O}_{2}$ with low oxidation of ASA by $\mathrm{H}_{2} \mathrm{O}_{2}$ as a control. The reaction was conducted in a mixture containing $50 \mu \mathrm{l}$ of the enzyme extract, $1 \mathrm{ml}$ of $0.68 \mathrm{mM}$ ASA, $1 \mathrm{ml}$ of $4 \mathrm{mM} \mathrm{H}_{2} \mathrm{O}_{2}$, and $0.1 \mathrm{mM}$ EDTA in $0.1 \mathrm{M}$ phosphate buffer at $\mathrm{pH}$ 7.0. APX activity was expressed as nmol ASA $\min ^{-1} \mathrm{mg}$ protein ${ }^{-1}$.

Catalase activity was assessed as the ability to catalyze the decomposition of $\mathrm{H}_{2} \mathrm{O}_{2}$ according to the procedure described by Chance and Maehly (1955). The reaction was initiated by the addition of $\mathrm{H}_{2} \mathrm{O}_{2}$ to the crude extract. Two controls were used: one without $\mathrm{H}_{2} \mathrm{O}_{2}$ and one without enzyme extract. The reaction mixture contained $50 \mu \mathrm{l}$ enzyme extract, $1 \mathrm{ml}$ of $30 \mathrm{mM} \mathrm{H}_{2} \mathrm{O}_{2}$, and $1 \mathrm{ml}$ of $0.1 \mathrm{M}$ phosphate buffer, $\mathrm{pH}$ 7.0. The decrease in absorbance was measured at $240 \mathrm{~nm}$. CAT activity was expressed as mmol $\mathrm{H}_{2} \mathrm{O}_{2}$ min $^{-1} \mathrm{mg}$ protein ${ }^{-1}$.

POX activity was measured accordingly as described by Chance and Maehly (1955). The reaction was initiated by the addition of $\mathrm{H}_{2} \mathrm{O}_{2}$ to the crude extract. Two controls were used: without $\mathrm{H}_{2} \mathrm{O}_{2}$ and without guaiacol. The reaction was conducted in a mixture containing $50 \mu$ l of enzyme extract, $1 \mathrm{ml}$ of $1 \%$ guaiacol, $1 \mathrm{ml}$ of $0.2 \mathrm{~mol} / 1 \mathrm{H}_{2} \mathrm{O}_{2}$, and $1 \mathrm{ml}$ of $0.1 \mathrm{~mol} / 1$ phosphate buffer, $\mathrm{pH}$ 7.0. POX activity was measured as the oxidation of guaiacol at $470 \mathrm{~nm}$ $\left(\varepsilon=26.6 \mathrm{mM}^{-1} \mathrm{~cm}^{-1}\right)$ and was expressed as $\mathrm{mmol} \mathrm{H}_{2} \mathrm{O}_{2}$ $\min ^{-1} \mathrm{mg}$ protein $^{-1}$.

SOD activity was determined as described by Giannopolitis and Ries (1977). The ability of SOD to inhibit the photochemical reduction of 4-nitroblue tetrazolium chloride (NBT) was measured as described in Pukacka and Pukacki (2000). A non-irradiated reaction mixture was used as a control. The reaction mixture contained $50 \mu \mathrm{l}$ enzyme extract, $63 \mathrm{mM}$ NBT, $1.3 \mathrm{mM}$ riboflavin, $0.1 \mathrm{mM}$ dithiothreitol, and $50 \mu \mathrm{M}$ phosphate buffer. The reaction mixture from test samples was placed in glass test tubes and illuminated. The amount of enzyme required to cause 50\% inhibition of the rate of NBT reduction was defined as one unit of SOD activity $\left(\mathrm{U} \mathrm{mg}^{-1}\right.$ protein).

Bovine serum albumin was used as a standard to estimate protein concentration of crude enzyme extracts (Bradford 1976).

ROS levels were determined on the same day, on freshly sampled needles that had been placed on ice immediately after collection. The level of superoxide $\left(\mathrm{O}_{2}^{-}\right)$was determined according to the method described by Doke (1983). The capacity to reduce nitroblue tetrazolium (NBT) in the dark at room temperature was determined. Samples were incubated in $3 \mathrm{ml}$ of $0.05 \mathrm{M} \mathrm{K}$-phosphate buffer ( $\mathrm{pH} 7.8$ ) containing $0.05 \% \mathrm{NBT}$ and $10 \mathrm{mM}$ sodium azide, at room temperature in the darkness, for $30 \mathrm{~min}$. Then, $2 \mathrm{ml}$ of sample were heated to $85^{\circ} \mathrm{C}$ for $15 \mathrm{~min}$ and subsequently cooled on ice. The final product absorbance was measured at $530 \mathrm{~nm}$ and $\mathrm{O}_{2}^{-}$content was expressed as $\Delta \mathrm{A} 530 \mathrm{~g}$ fresh weight $^{-1}$. Finely powdered fresh needles were homogenized 
in 5\% trichloroacetic acid containing $10 \mathrm{mM}$ EDTA to measure hydrogen peroxide $\left(\mathrm{H}_{2} \mathrm{O}_{2}\right)$. The homogenate was centrifuged at $26,000 \mathrm{~g}$ for $20 \mathrm{~min}$ and $4{ }^{\circ} \mathrm{C}$. The ferrithiocyanate method was used to analyze the total amount of hydrogen peroxide in the supernatant (Sagisaka 1976).

\section{Chlorophyll and carotenoids concentration}

Chlorophyll and carotenoid concentration were determined according to the methods described by Barnes et al. (1992). Approximately, $25 \mathrm{mg}$ of fresh needles were cut into small pieces (about $1 \mathrm{~mm}^{2}$ ) and incubated for $4 \mathrm{~h}$ in $4 \mathrm{ml}$ of $100 \%$ dimethyl sulfoxide (DMSO) saturated with $\mathrm{CaCO}_{3}$ at $60{ }^{\circ} \mathrm{C}$. The incubation continued until needles lost all color. The absorbance of the extract was measured at 665,648 , and $470 \mathrm{~nm}$ in a Cary $60 \mathrm{UV}-\mathrm{V}$ is spectrophotometer (Agilent Technologies). A solution of DMSO was used as a blank.

\section{Measurements of chlorophyll $a$ fluorescence}

Fluorescence measurements were conducted using a Fluorescence Monitoring System (FMS 2, Hansatech, Norfolk, UK) operating in an online mode according to the procedure described by Robakowski et al. (2018). On each occasion, needles were harvested from four plants per fertilization treatment per sex per block $(n=8)$, wrapped in moist paper, placed in an Eppendorf tube, and left in darkness for $30 \mathrm{~min}$ at room temperature $\left(21-22^{\circ} \mathrm{C}\right.$, min-max) before measuring fluorescence. Then, 4-5 needles were placed close to each other, abaxial surface facing down, on a piece of transparent, self-adhesive tape, and introduced into a leaf clip. Needles among those collected for the fluorescence measurements were also used to determine a leaf mass-to-area ratio (LMA).

A minimum $\left(F_{0}\right)$ and a maximum fluorescence values $\left(F_{\mathrm{m}}\right)$ as well as steady state fluorescence $\left(F_{\mathrm{s}}\right)$ and maximum light-adapted fluorescence $\left(F_{\mathrm{m}}^{\prime}\right)$ were measured accordingly to Robakowski et al. (2018). Maximum quantum yield of PSII photochemistry was calculated according to the following formula: $F_{\mathrm{v}} / F_{\mathrm{m}}=\left(F_{\mathrm{m}}-F_{0}\right) / F_{\mathrm{m}}$.

A quantum yield of PSII photochemistry $\left(\Phi_{\mathrm{PSII}}\right)$ was calculated for each light level according to the formula: $\Phi_{\mathrm{PSII}}=\left(F_{\mathrm{m}}^{\prime}-F_{\mathrm{s}}\right) / F_{\mathrm{m}}^{\prime}$ (Genty et al. 1989); non-photochemical quenching of fluorescence (NPQ) was calculated with $\mathrm{NPQ}=\left(F_{\mathrm{m}}-F_{\mathrm{m}}^{\prime}\right) / F_{\mathrm{m}}^{\prime}$ (Maxwell and Johnson 2000); an apparent electron transport rate (ETR) with ETR $=\alpha \times \Phi_{\text {PSII }} \times 0.5 \times$ PPF, where $\alpha$-needle absorptance and 0.5 factor means the assumption that both photosystems obtained an equal amount of excitation energy (Maxwell and Johnson 2000).

Since leaf absorptance may be species specific and undergo adaptation to microclimate conditions, the leaf absorptance value was calculated from total chlorophyll concentration according to the empirical model provided by Evans (1993).

\section{Determination of cardinal points of light response curves}

To determine the cardinal points of light response curves, the maximum apparent rate of photosynthetic electron transport of PS II (ETR $\left.\max _{\max }\right)$ and the saturation level of photosynthetic photon flux density $\left(\mathrm{PPF}_{\mathrm{sat}}\right)$, were fitted to the functions developed by Ye et al. (2013): $\mathrm{ETR}_{\max }=\alpha\left(\frac{\sqrt{\beta+\gamma}-\sqrt{\beta}}{\gamma}\right)^{2}$ and $\mathrm{PPF}_{\text {sat }}=\frac{\sqrt{(\beta+\gamma) / \beta}-1}{\gamma}$, where $\alpha$-initial slope of light response curve of ETR, $\beta$-range of light response curve of dynamic down-regulation of PSII and $\gamma$-a saturation term of light response curve for photosynthetic electron transport rate (ETR-PPF; where PPF is photosynthetic photon flux). ETR values increase with increasing PPF until it reaches saturation irradiance $\left(\mathrm{PPF}_{\mathrm{sat}}\right.$ at which $\left.\mathrm{ETR}=\mathrm{ETR}_{\mathrm{max}}\right)$, but then decreases because of down-regulation of PSII in high irradiance.

To determine the maximum value of quantum yield of PSII photochemistry at the saturation value of $\operatorname{PPF}\left(\Phi_{\mathrm{PPF}_{\mathrm{sat}}}\right)$, the following formula was used (Rascher et al. 2000; Robakowski 2005):

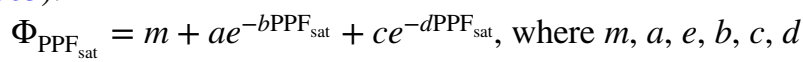
are independent parameters.

PPF versus NPQ was fitted with the exponential function: $\mathrm{NPQ}=m+a(1-e(-b \mathrm{PPF}))$.

NPQ increases to infinity with actinic light (Maxwell and Johnson 2000). Therefore, values of $\mathrm{NPQ}_{530}$ at the arbitrary chosen $\mathrm{PPF}$ value $=530 \mu \mathrm{mol} \mathrm{m}^{-2} \mathrm{~s}^{-1}$ were used in statistical analysis.

\section{Statistical analysis}

All data were tested for normality with the Shapiro-Wilk's test and the homogeneity of variance was evaluated using the Levene's test. Data were subsequently analyzed using a two-way ANOVA with sex and fertilization treatment as the sources of fixed effects and with blocks as the source of random effects. Analyses were run at each sampling date. When the interaction between sex and fertilization treatment occurred, the Tukey's post hoc test was used to find differences between means. Means were considered to differ statistically at $P<0.05$. Data were presented as means with standard errors (SE). Statistical analysis was conducted using JMP 13 software (SAS Institute Inc., Cary, NC, USA 1989-2007). Figures were prepared in R package (R Core Team 2018). 


\section{Results}

\section{Light response curves}

Curves for $\Phi_{\text {PSII }}$ and ETR vs. PPF were both higher in fertilized individuals than in non-fertilized individuals and the mean values of $\Phi_{\text {PSII }}$ and ETR were significantly different between the fertilization treatments from the low PPF values (Fig. 1a, b). The fertilization treatment also affected the loss of absorbed energy from needles as heat, expressed as NPQ, which was significantly higher in non-fertilized plants in the range of $45 \mu \mathrm{mol} \mathrm{m} \mathrm{m}^{-2} \mathrm{~s}^{-1}$ to $530 \mu \mathrm{mol} \mathrm{m} \mathrm{m}^{-2} \mathrm{~s}^{-1}$ actinic PPF (Fig. 1c). Similarly to fertilization, the sex also had a significant effect on the shape of curves of $\Phi_{\mathrm{PSII}}$, ETR, and NPQ vs. PPF. Female ( + ) plants had significantly lower values of $\Phi_{\text {PSII }}$ than male ( ${ }^{\pi}$ ) plants (e.g., . $: 0.12 \pm 0.01$ vs. $\delta: 0.14 \pm 0.01$ at $783 \mu \mathrm{mol} \mathrm{m}{ }^{-2} \mathrm{~s}^{-1}$ of fluorescence induction light, Fig. 1d) and ETR (e.g.,,$: 59.78 \pm 4.03$ vs. $\delta^{\lambda}$ : $71.62 \pm 4.81$ at $1075 \mu \mathrm{mol} \mathrm{m}^{-2} \mathrm{~s}^{-1}$ of fluorescence induction light, Fig. 1e), but significantly higher values of NPQ (e.g., q: $2.40 \pm 0.08$ vs. $\delta^{-}: 2.28 \pm 0.08$ at $345 \mu \mathrm{mol} \mathrm{m} \mathrm{m}^{-2} \mathrm{~s}^{-1}$ of fluorescence induction light, Fig. 1f).

\section{Time-related changes in chlorophyll $a$ fluorescence-based parameters}

All of the chlorophyll $a$ fluorescence-based parameter $\left(\mathrm{PPF}_{\text {sat }}, \mathrm{ETR}_{\text {max }}, F_{\mathrm{v}} / F_{\mathrm{m}}, \Phi_{\mathrm{PPF}_{\text {sat }}}\right.$ and $\left.\mathrm{NPQ}_{530}\right)$ differed significantly between the F and NF (Fig. 2a-e, S-Table 1). ETR $_{\text {max }}$ had significantly higher values in fertilized plants within all but one sampling time points (e.g., July, 2016 F: $74.86 \pm 3.74$ vs. NF: $54.58 \pm 3.74, P=0.001$, Fig. 2a). Lower $\Phi_{\mathrm{PPF}_{\text {sat }}}$ values were observed in general in fertilized than non-fertilized plants (e.g., July, 2016 F: $0.12 \pm 0.004$ vs. NF: $0.14 \pm 0.004, P=0.038$, Fig. $2 b$ ). However, fertilized plants had higher values of $F_{\mathrm{v}} / F_{\mathrm{m}}$ (e.g., July, 2016: $0.92 \pm 0.002$, Fig. 2c) and $P P_{\text {sat }}$ (e.g., July, 2016: $1226.43 \pm 56.44$, Fig. $2 d)$ when compared to nonfertilized plants $\left(F_{\mathrm{v}} / F_{\mathrm{m}}: 0.91 \pm 0.002, P=0.018 ; \mathrm{PPF}_{\mathrm{sat}}\right.$ : $803.82 \pm 56.44, P<0.001)$. Values of $\mathrm{NPQ}_{530}$ were significantly different between fertilized and non-fertilized plants only within two sampling time points (in July 2015 and October 2016, Fig. 2e).

In May 2015 and in July 2016, ETR max $_{\text {values were }}$ higher in male when compared to female plants (e.g., July 2016 : $: 71.51 \pm 3.74$ vs. + : $57.93 \pm 3.74, P=0.016$, Fig. 3a). Values of $F_{\mathrm{v}} / F_{\mathrm{m}}$ were significantly different between the sexes; however, it was true within two sampling points (May 2015 and January 2016, Fig. 3b). These values were on one date higher in females (May
Fig. 1 Photosystem II (PSII) quantum yield $\left(\Phi_{\text {PSII }}, \mathbf{a}, \mathbf{d}\right)$ apparent electron transfer rate (ETR, b, e) and nonphotochemical quenching of fluorescence (NPQ, $\mathbf{c}, \mathbf{f})$ versus photosynthetic photon flux $(\mathrm{PPF})$ in needles from fertilized (green) vs. non-fertilized (grey) $(\mathbf{a}, \mathbf{b}, \mathbf{c})$ plants of Juniperus communis and male (blue) vs. female (pink) plants (d, e, f). Measurements of chlorophyll $a$ fluorescence were conducted in July, 2016. Data are means with standard errors (SE, $n=16$ ). Asterisks indicate significant differences between fertilization treatments or sexes at each value of $\operatorname{PPF}\left({ }^{*} P<0.05\right.$; $\left.{ }^{* * *} P<0.01 ;{ }^{* * *} P<0.001\right)$
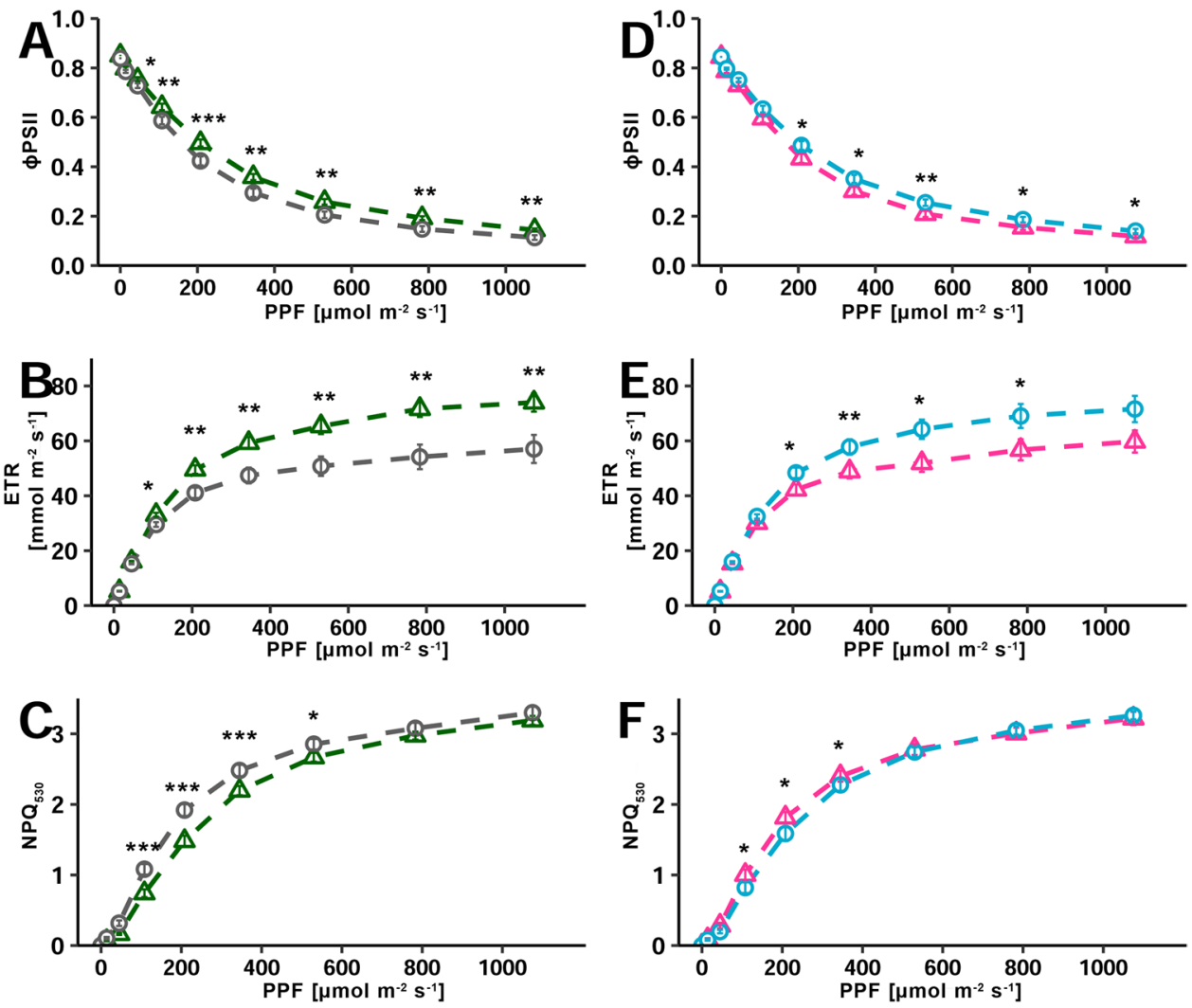
Fig. 2 Seasonal changes in photosynthetic parameters in needles of Juniperus communis L. individuals of plants grown with (green) or without fertilization (grey). a Apparent maximum electron transport rate $\left(\mathrm{ETR}_{\max }\right)$ $\left(\mu \mathrm{mol} \mathrm{m} \mathrm{m}^{-2} \mathrm{~s}^{-1}\right)$; b quantum yield of PSII photochemistry at the saturation value of photosynthetic photon flux $\left(\Phi_{\mathrm{PPF}_{\mathrm{sat}}}\right)$; c maximum quantum yield of PSII photochemistry $\left(F_{\mathrm{v}} / F_{\mathrm{m}}\right)$; d saturation photosynthetic photon flux corresponding to maximum electron transport rate $\left(\mathrm{PPF}_{\mathrm{sat}}\right)\left(\mu \mathrm{mol} \mathrm{m} \mathrm{m}^{-2} \mathrm{~s}^{-1}\right)$; e non-photochemical quenching of fluorescence at $\mathrm{PPF}=530 \mu \mathrm{mol} \mathrm{m} \mathrm{m}^{-2} \mathrm{~s}^{-1}$ $\left(\mathrm{NPQ}_{530}\right) ; \mathbf{f}$ total chlorophyll (mg g $\left.{ }^{-1} \mathrm{DW}\right) ; \mathbf{g}$ chlorophyll $a / b$ ratio; $\mathbf{h}$ carotenoids $\left(\mathrm{mg} \mathrm{g}^{-1}\right.$ DW); i leaf mass-to-area ratio $\left(\mathrm{LMA} \mathrm{gm}^{-2}\right)$; $\mathbf{j}$ needle absorptance. Data are means with standard errors (SE, $n=16)$. Asterisks indicate statistical differences between means at ${ }^{*} P<0.05 ;{ }^{* *} P<0.01$; ${ }^{* * * *} P<0.001$
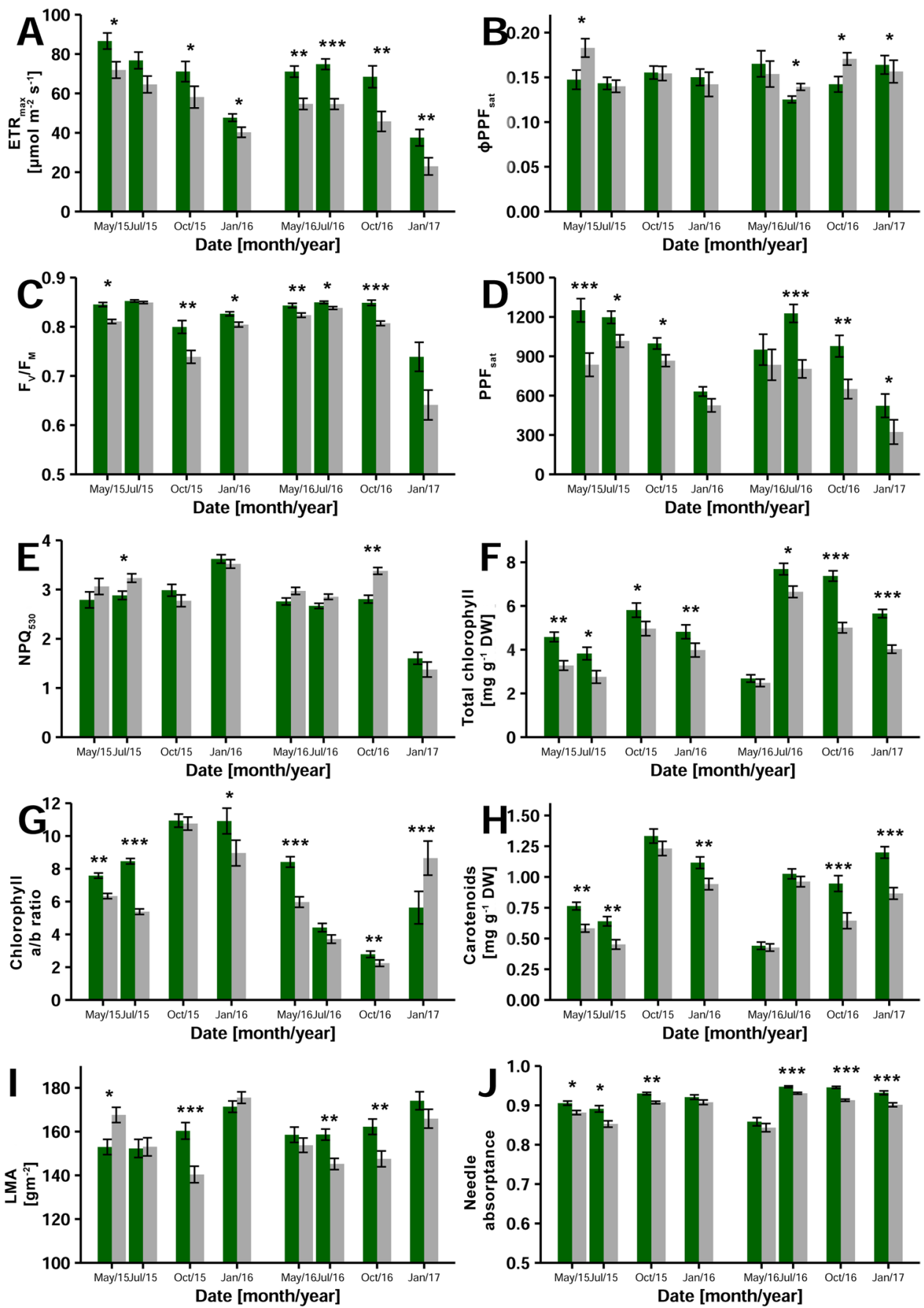

2015 우: $0.912 \pm 0.001$ vs. $\delta^{1}: 0.907 \pm 0.001, P=0.050$ ), otherwise in males (January 2016 \&: $0.897 \pm 0.003$ vs. $\delta: 0.909 \pm 0.003, P=0.012$ ). Moreover, male plants had higher values of $\Phi_{\mathrm{PPF}_{\text {sat }}}$ (in January $2017 \delta^{\top}: 0.17 \pm 0.01$,

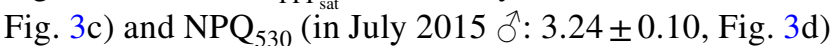
than female plants $\left(\Phi_{\mathrm{PPF}_{\text {sat }}}\right.$ 古: $0.15 \pm 0.01, P=0.05 ; \mathrm{NPQ}_{530}$ ㅇ: $2.88 \pm 0.10, P=0.020)$. No interaction between fertilization treatment and sex was noticed for values of chlorophyll $a$ fluorescence-based parameters.

\section{Time course changes in total chlorophyll and carotenoids concentration, absorptance and leaf-mass-to-area ratio}

Total chlorophyll, chlorophyll $a / b$ ratio, carotenoid concentration as well as LMA values were affected by lack of fertilization regardless to sampling date (Fig. 2f-j; S-Table 2). Non-fertilized plants had significantly lower concentration of total chlorophyll than fertilized plants, especially in autumn (e.g., October 2016 NF: $5.01 \pm 0.32$ vs. F: $7.37 \pm 0.32$, 
Fig. 3 Seasonal changes in leaf parameters in needles of male (blue) or female (pink) Juniperus communis L. plants: a apparent maximum electron transport rate $\left(\mathrm{ETR}_{\max }\right)$ $\left(\mu \mathrm{mol} \mathrm{m}{ }^{-2} \mathrm{~s}^{-1}\right)$; b maximum quantum yield of PSII photochemistry $\left(F_{\mathrm{v}} / F_{\mathrm{m}}\right) ; \mathbf{c}$ quantum yield of PSII photochemistry at the saturation value of photosynthetic photon flux $\left(\Phi_{\mathrm{PPF}_{\text {sat }}}\right), \mathbf{d}$ non-photochemical quenching of fluorescence at $\mathrm{PPF}=530 \mu \mathrm{mol} \mathrm{m} \mathrm{m}^{-2} \mathrm{~s}^{-1}$ $\left(\mathrm{NPQ}_{530}\right) ;$ e total chlorophyll ( $\left.\mathrm{mg} \mathrm{g}^{-1} \mathrm{DW}\right)$; $\mathbf{f}$ carotenoids (mg g $\left.{ }^{-1} \mathrm{DW}\right)$; $\mathbf{g}$ leaf mass-toarea ratio (LMA, $\mathrm{gm}^{-2}$ ); h needle absorptance. Data are means with standard errors (SE, $n=16$ ). Asterisks indicate statistical differences between means at ${ }^{*} P<0.05 ;{ }^{* *} P<0.01$; ${ }^{* * * *} P<0.001$
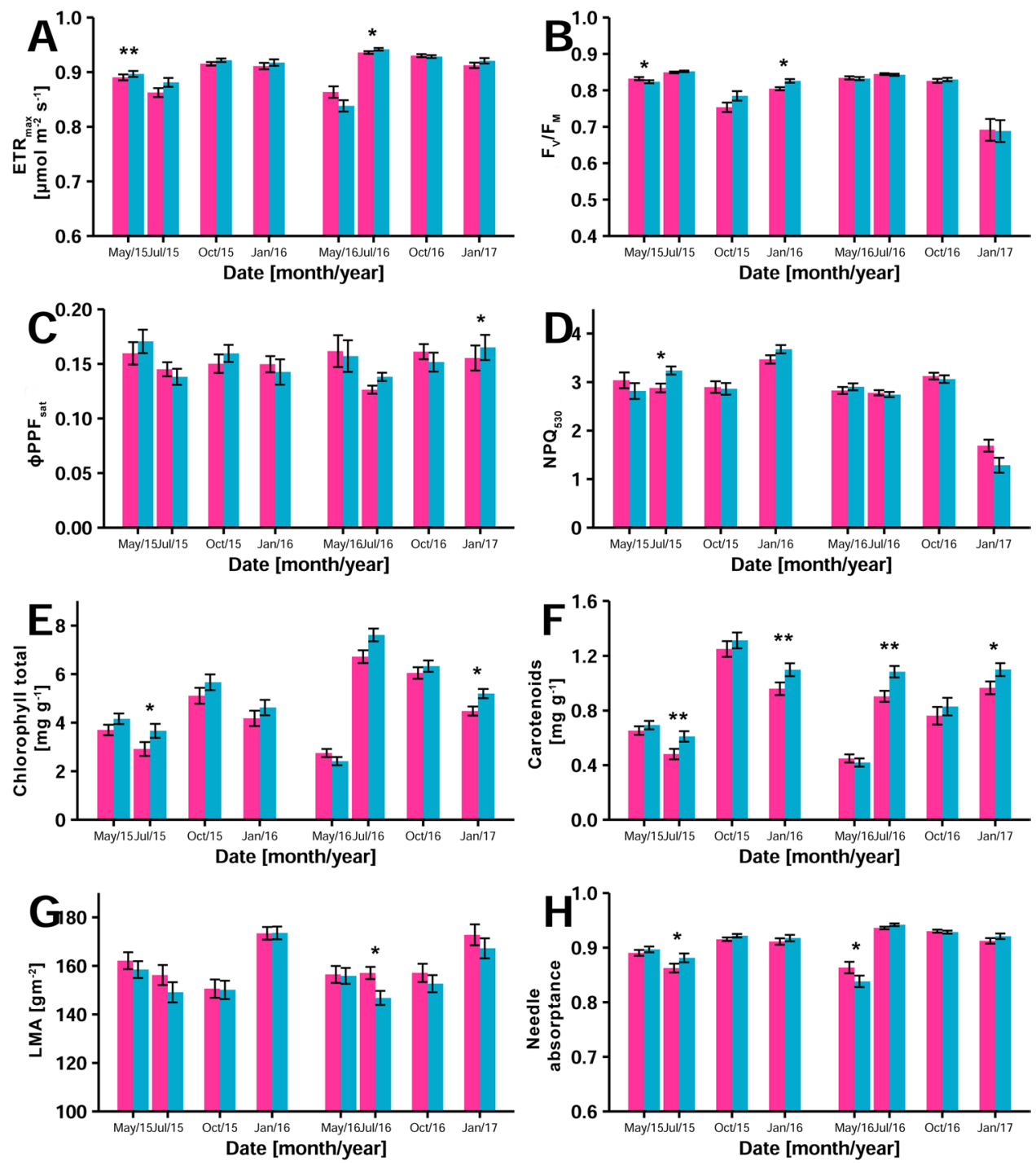

$P<0.0001$ ) and winter (e.g., January 2017 NF: $3.58 \pm 0.13$ vs. F: $4.76 \pm 0.14, P<0.0001$, Fig. $2 \mathrm{f}$ ) as well as by lower chlorophyll $a / b$ ratio (Fig. $2 \mathrm{~g}$ ). Moreover, non-fertilized plants were characterized by lower carotenoid concentration (e.g., October 2016 NF: $0.64 \pm 0.04$ vs. F: $0.95 \pm 0.04$, $P<0.0001$; January $2017: 0.87 \pm 0.04$ vs. F: $1.20 \pm 0.04$, $P<0.0001$, Fig. 2 h). This was accompanied by lower LMA in autumn (e.g., October 2016 NF: $147.52 \pm 3.95$ vs. F: $162.30 \pm 3.83, P=0.0127$ ), but not in winter (e.g., January $2017 \mathrm{NF}: 165.38 \pm 4.37$ vs. F: $174.10 \pm 4.23, P=0.189$, Fig. 2i) and by lower needle absorptance observed in nonfertilized plants at both sampling dates (e.g., October 2016 NF: $0.91 \pm 0.003$ vs. F: $0.95 \pm 0.003, P<0.0001$; January 2017 NF: $0.90 \pm 0.01$ vs. F: $0.93 \pm 0.01, P<0.0001$, Fig. 2 j).

Female plants had significantly lower total chlorophyll concentration in July 2015 ( $9: 2.91 \pm 0.20$ vs. $\delta^{7}$ : $3.66 \pm 0.20, P=0.015)$ and January 2017 ( $9: 4.48 \pm 0.18$ vs. ${ }^{\top}: 5.20 \pm 0.19, P=0.010$, Fig. 3e). In both years, female had lower carotenoid concentration than male plants, and significant differences between sexes occurred in July (e.g., in 2016 : $0.90 \pm 0.04$ vs. $\delta: 1.08 \pm 0.04, P=0.004$ ) and January (e.g., in 2016 $O$ : $0.96 \pm 0.03$ vs. $\delta^{\text {t }}: 1.10 \pm 0.03$, $P=0.007$; Fig. 3f, Table S1). Moreover, the significant interaction between the sex and fertilization treatments on carotenoids concentration were detected in January 2015 $(P=0.004)$ and in June $2016(P=0.029)$. In January 2015, fertilized male plants $(\mathrm{F} \delta: 1.26 \pm 0.05$ a) had the higher carotenoid concentration than other groups $(\mathrm{F}$ $0: 0.97 \pm 0.05$ b; NF $\bigcirc: 0.95 \pm 0.05 \mathrm{~b}$ and NF $\delta$ : $0.94 \pm 0.05 \mathrm{~b}, P=0.004$ ). In July 2016, carotenoid concentration had the highest value in males regardless to fertilization (NF $\delta^{\lambda}: 1.12 \pm 0.06$ a and $\mathrm{F} \delta^{\lambda}: 1.05 \pm 0.06 \mathrm{a}$ ), whereas non-fertilized females had the lowest value $(0: 0.81 \pm 0.06 \mathrm{~b})$ and fertilized female plants were similar to all of above ( $($ : $1.00 \pm 0.06 \mathrm{ab}, P=0.0285$ ). Female plants had also higher LMA, but significant differences were observed only in July 2016 ( $(: 156.78 \pm 3.13$ 
vs. $\delta$ : $147.35 \pm 3.23, P=0.0465$, Fig. $3 g$ ). Moreover, the significant interaction between sex and fertilization treatment on LMA was observed in June $2016(P=0.048)$, thus non-fertilized male plants (NF $\widehat{\delta}: 135.8 \pm 4.57 \mathrm{~b}$ ) had the lowest LMA value when compared with other groups of plants [female non-fertilized (NF 9 : $154.58 \pm 4.57 \mathrm{a}$ ), male fertilized $(\mathrm{F} \hat{\sigma}: 158.91 \pm 4.57 \mathrm{a})$ and female fertilized (F $9: 158.97 \pm 4.27$ a) $]$. Needle absorptance was significantly lower in female plants $(Q: 0.86 \pm 0.006)$ when compared with male plants ( $\delta$ : $0.88 \pm 0.006 ; P=0.05)$ in July 2015; however, in May 2016, the opposite relationship was observed-female ( $9: 0.864)$ had higher needle absorptance than male plants ( $\sigma^{\lambda}: 0.840 \pm 0.007, P=0.018$, Fig. 3 h).

\section{Antioxidant enzymes activity and reactive oxygen species}

Needles for fertilized $(\mathrm{F})$ plants exhibited higher enzyme activity and a lower concentration of free radicals $\left(\mathrm{O}_{2}^{-}\right.$and $\mathrm{H}_{2} \mathrm{O}_{2}$ ) than needles from non-fertilized (NF) plants, especially within the first season of sampling (Fig. 4, S-Table 3). The activity of most of the antioxidant enzymes was higher in fertilized plants in July, 2015 (APX 1.27 \pm 0.04 ; POX $0.21 \pm 0.01$; SOD $37.77 \pm 1.78)$ than in non-fertilized plants (APX 1.00 $\pm 0.04, P=0.002$; POX 0.14 $\pm 0.01, P=0.005$; SOD $29.29 \pm 1.78, P=0.005)$ (Fig. $4 \mathrm{a}, \mathrm{c}, \mathrm{d})$. In contrast, only the activity of CAT was higher in fertilized plants $(0.21 \pm 0.02)$ than in non-fertilized plants $(0.15 \pm 0.01$, $P=0.005$, Fig. 4b) in July, 2016. Additionally, the level of free radicals on this sampling date was lower in needles of fertilized plants $\left(\mathrm{O}_{2}^{-} 1.53 \pm 0.22 ; \mathrm{H}_{2} \mathrm{O}_{2} 24.33 \pm 2.79\right)$ than in needles of non-fertilized plants $(2.55 \pm 0.27, P=0.007$ and $35.03 \pm 2.79, P=0.011$, respectively, Fig. $4 \mathrm{e}, \mathrm{f})$.

Plant sex had a significant effect on antioxidant enzyme activity and on the level of $\mathrm{H}_{2} \mathrm{O}_{2}$ (Fig. 5a-d). Specifically, in October, 2015, higher level of $\mathrm{H}_{2} \mathrm{O}_{2}$ was observed in needles of female plants $(q: 27.92 \pm 2.02$ vs. $\hat{\sigma}: 20.76 \pm 1.95$, $P=0.017$, Fig. 5a) and also SOD activity was lower in needles of female plants $(24.80 \pm 1.90)$ than in needles of male plants $(30.29 \pm 1.90, P=0.046$, Fig. $5 c)$. During October, 2016, the level of $\mathrm{H}_{2} \mathrm{O}_{2}$ was lower in needles of female plants $(74.49 \pm 2.84)$ than in needles of male plants $(84.76 \pm 2.84$, $P=0.036)$, which was inversely related to the level of APX activity observed in needles of female $(q: 1.16 \pm 0.10$ vs. $\widehat{\delta}: 0.85 \pm 0.10, P=0.048$, Fig. 5b). Male plants had higher CAT activity $(\delta: 0.085 \pm 0.007)$ than female plants $(q$ : $0.063 \pm 0.007, P=0.033$, Fig. $5 d$ ) in January 2016. No interaction between fertilization treatment and sex was observed for enzymes activity and the concentration of free radicals.
Fig. 4 Seasonal changes in photosynthetic parameters in needles of Juniperus communis L. individuals of plants grown with (green) or without fertilization (grey). a ascorbate peroxidase (1 nmol ASA min ${ }^{-1}$ mg protein $^{-1}$, APX); $\mathbf{b}$ catalase (mmol $\mathrm{H}_{2} \mathrm{O}_{2}$ min $^{-1}$ mg protein $^{-1}, \mathrm{CAT}$ ); $\mathbf{c}$ guaiacol peroxidase (nkat min $^{-1} \mathrm{mg}$ protein ${ }^{-1}$, POX); $\mathbf{d}$ superoxide dismutase (U mg protein $\left.{ }^{-1}, \mathrm{SOD}\right)$; e hydrogen peroxide ( $\mu \mathrm{g} \mathrm{g}^{-1} \mathrm{DW}$, $\left.\mathrm{H}_{2} \mathrm{O}_{2}\right)$; f superoxide $\left(\mu \mathrm{g} \mathrm{g}^{-1}\right.$ $\mathrm{DW}, \mathrm{O}_{2}^{-}$) ascorbate peroxidase (1 nmol ASA min ${ }^{-1} \mathrm{mg}$ protein $^{-1}$, APX), Data are means with standard errors (SE, $n=16)$. Asterisks indicate statistical differences between means at ${ }^{*} P<0.05 ;{ }^{* *} P<0.01$; ${ }^{* * *} P<0.001$
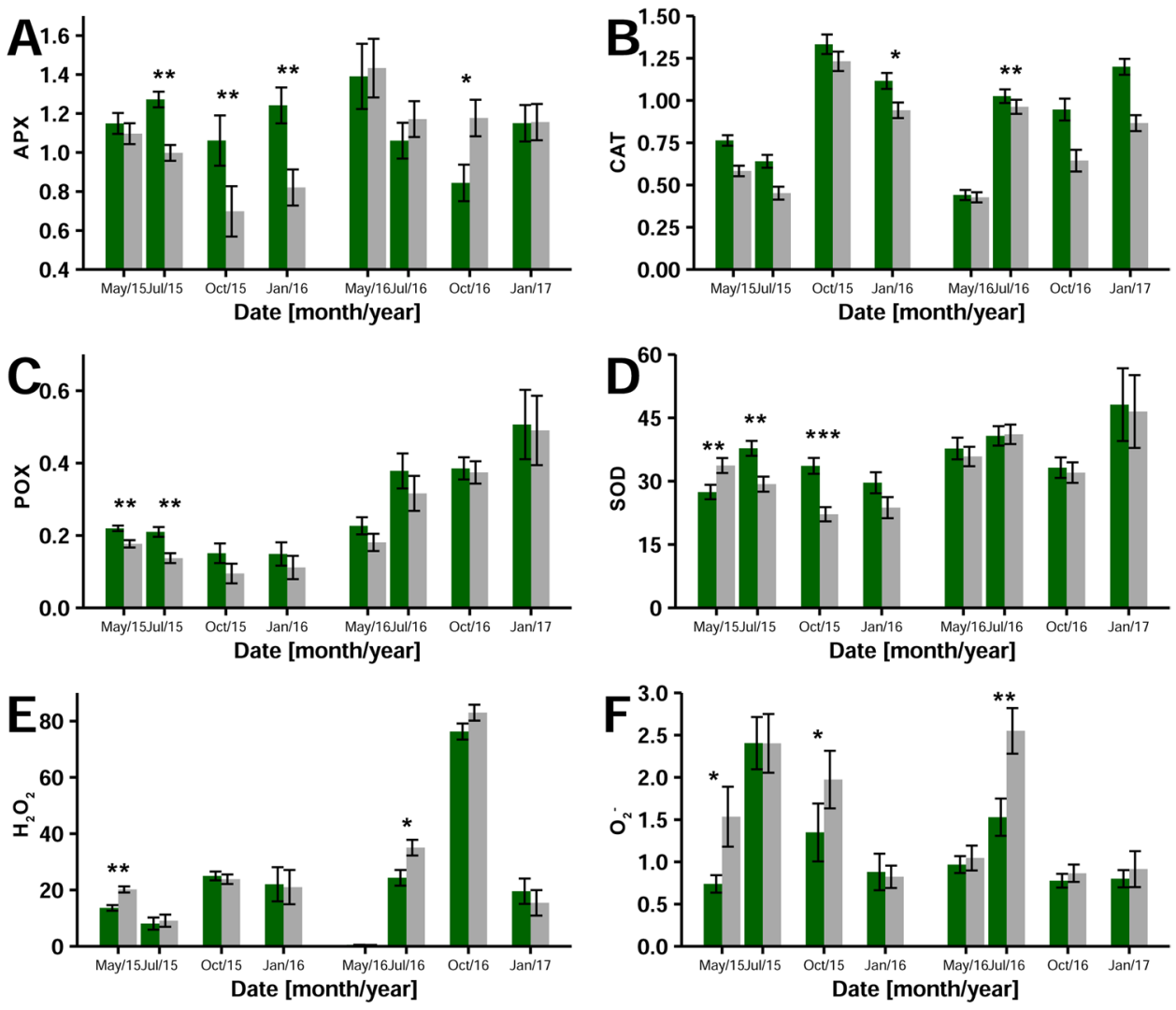
Fig. 5 Seasonal changes in leaf parameters in needles of male (blue) or female (pink)

Juniperus communis L. plants: a hydrogen peroxide $\left(\mu \mathrm{g} \mathrm{g}^{-1}\right.$ DW, $\mathrm{H}_{2} \mathrm{O}_{2}$ ), b ascorbate peroxidase (1 nmol ASA

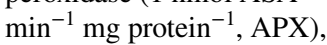
c superoxide dismutase (U mg protein ${ }^{-1}$, SOD), d catalase $\left(\mathrm{mmol} \mathrm{H}_{2} \mathrm{O}_{2}\right.$ $\min ^{-1} \mathrm{mg}$ protein ${ }^{-1}$, CAT). Data are means with standard errors (SE, $n=16)$. Asterisks indicate statistical differences between means at ${ }^{*} P<0.05 ;{ }^{* * *} P<0.01$
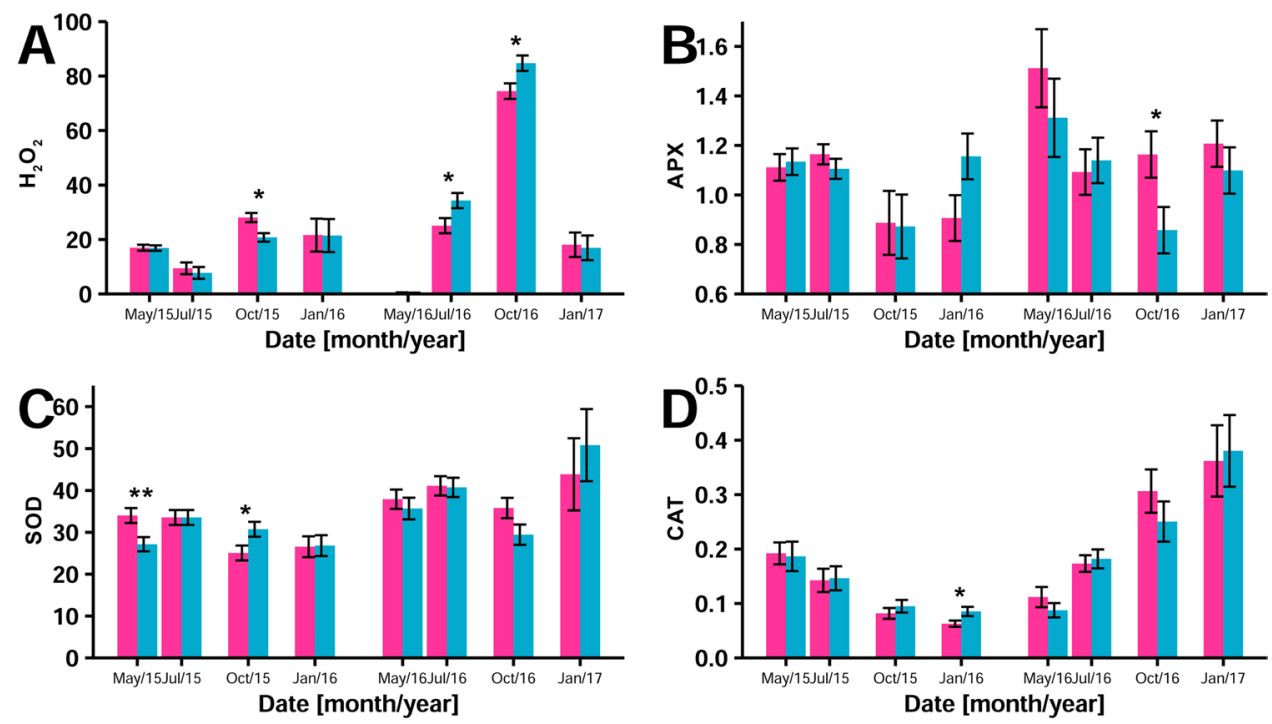

\section{Discussion}

In needles of $J$. communis plants, sex-related differences were found in photochemical parameters, the concentration of photosynthetic pigments, LMA, and $\mathrm{H}_{2} \mathrm{O}_{2}$ and in antioxidant enzyme activity. Results indicate that needles from male plants have a higher photosynthetic capacity than female plants, as determined by ETR $\mathrm{max}_{\max }, \Phi_{\mathrm{PPF}_{\mathrm{sat}}}$, and a higher concentration of photosynthetic pigments, and female plants had higher LMA. In our experiment, due to higher needle carotenoid concentration even under limited nutritional conditions, abiotic stress could affect male plants less than female plants. We did not observe, however, the consistent relationship between sex and antioxidant enzymes activity and ROS formation. Our study showed the significant impact of nutritional availability on photochemical parameters, the concentration of photosynthetic pigments, antioxidant enzyme activity, and the formation of ROS in J. communis.

In accordance to our hypothesis, J. communis male plants exhibit a greater ability to maintain higher photosynthetic activity than female plants and they do this regardless of nutrient availability. On certain dates, needles of male plants had the higher values of $\mathrm{ETR}_{\mathrm{max}}, \Phi_{\mathrm{PPF}_{\mathrm{sat}}}$ and $\mathrm{NPQ}_{530}$ than needles of female plants, as well as the higher concentration of total chlorophyll and carotenoids, but the lower LMA. Recent studies on Salix paraplesia revealed an opposite situation when female plants had higher values of, inter alia, net $\mathrm{CO}_{2}$ assimilation rates, and chlorophyll concentration. However, opposite to J. communis, this species shows female-biased sex ratio (Liao et al. 2019). The higher LMA in female J. communis plants suggests that their needles are thicker with more developed palisade parenchyma than male needles, which can be considered as a structural leaf adaptation to high light (Givnish 1988).
Resource availability can affect male and female individuals differently, with males being more tolerant to resource limitation than female plants (Montesinos et al. 2012; Zhang et al. 2014), which can result from different preferences in nitrogen sources (Zhao et al. 2018) or different strategies of growth $v s$ defense trade-offs (Jiang et al. 2016). Juniperus communis females exhibit lower photosynthetic capacity than males, which can result from greater reproductive effort of females in this species (Iszkuło and Boratyński 2011). In dioecious species, however, females can compensate for a greater reproductive effort by increased gas exchange per leaf area unit, greater stomatal density, or greater leaf area relative to male plants (Wallace and Rundel 1979; Kohorn 1994; Meagher 1999; Obeso 2002; Montesinos et al. 2012; Iszkuło et al. 2013). Additionally, male and female plants can exhibit different levels of sensitivity to different stresses (Zhang et al. 2017; Qin et al. 2018). Importantly, stress tolerance can be constitutive and/or induced based on the genetics of the species (reviewed in Geber et al. 1999).

In the present study, $\mathrm{ETR}_{\max }$ and $\Phi_{\mathrm{PPF}_{\mathrm{sat}}}$ values were higher in J. communis males than in females. $F_{\mathrm{v}} / F_{\mathrm{m}}$ value was higher in females during flowering and it was opposite in winter.

Our results for photosynthetic parameters are in agreement with previous studies on Pistacia lentiscus (Correia and Diaz Barradas 2000) and Populus cathayana Xu et al. (2008), but they are not consistent with the results reported by Mitchell (1998) for Taxus baccata and T. brevifolia, who did not detect any differences between sexes in foliar physiology. However, similarly to our results, the value of $F_{\mathrm{v}} / F_{\mathrm{m}}$ in Pistacia lentiscus was higher in female plants than male plants, especially during spring (Ait Said et al. 2013). Also T. baccata males had a lower $F_{\mathrm{v}} / F_{\mathrm{m}}$ than females but no sex-based differences in $\mathrm{ETR}_{\text {max }}$ and $\mathrm{PPF}_{\text {sat }}$ were observed (Robakowski et al. 2018). 
The results of the present study indicate that the greater reproductive effort in female plants can manifest itself in lower photosynthetic activity. This was shown already in Populus purdomii, where males had greater photosynthetic capacity than females as well as lower construction costs (Lei et al. 2017a). We hypothesize that although females of J. communis exhibit a greater reproductive effort than males (Iszkuło and Boratyński 2011), they compensate for it in a manner other than increasing photosynthetic efficiency, as occurs in Silene latifolia (Gehring and Monson 1994). The compensation in J. communis may be brought about by the greater leaf area in female plants (Nowak-Dyjeta et al. 2017). The higher LMA in J. communis females suggests that females had thicker leaves and fertilization did not affect leaf structure in females as remarkably as in males. Moreover, females can achieve the same or even higher production of carbohydrates than males at the whole plant level (Nicotra et al. 2003). Females can also differ from males in regards to resource allocation (Gehring and Monson 1994), as nitrogen content in J. communis was reported to be higher in female needles before flowering (Nowak-Dyjeta et al. 2017). What is significant, greater nitrogen storage in J. thurifera shoot increased photosynthesis of male but did not affect female photosynthesis (Montesinos et al. 2012).

Higher ETR $_{\max }$ values in needles of male plants suggest a greater tolerance of their photosynthetic apparatus to photoinhibition relative to needles in female plants. Significantly, higher $\mathrm{ETR}_{\max }$ values in males occurred during flowering in the first year of our study and during a period of intensive growth in the second year. In both cases, differences between male and female plants appeared when the highest temperatures occurred. This may indicate that females cannot maintain their photosynthetic capacity relative to males during the periods of most intensive growth (reviewed in Song et al. 2018). In wind-pollinated species, males produce a great amount of pollen during flowering to increase their reproductive success and allocation in reproduction can be greater in males during that time (Rocheleau and Houle 2001). Because of that, males may increase photosynthetic efficiency to obtain the energy necessary for mating, and at the same time, they are more prone to loss of energy even after flowering is over.

In addition to greater photosynthetic efficiency, males in our study were characterized by higher total chlorophyll and carotenoid concentration, especially during intensive vegetative growth in July. Total chlorophyll concentration may be an indicator for estimating the potential of plants to adapt to an unfavorable environment (Croft et al. 2017; Li et al. 2018). The higher total chlorophyll concentration in male plants potentially suggests better performance (Barradas and Correia 1999) and is also related to plant maturity (Laporte and Delph 1996). Notably, relative to our results, chlorophyll content in Silene latifolia males was higher than in unpollinated females, but not pollinated females (Laporte and Delph 1996). Chlorophyll $a / b$ ratio, an indicator of leaf senescence and light growth conditions, did not differ between males and females suggesting that similar conditions for leaf expansion exist in both sexes (Adams et al. 1990). Additionally, a higher carotenoid concentration in male plants may indicate a greater ability to cope with stress, thus males are potentially better able to regulate ROS levels than females. Carotenoids, inter alia, protect the photosynthetic apparatus from photooxidative damage by quenching the triplet state of chlorophyll; thereby preventing the formation of harmful oxidative species, and also by directly quenching of activated oxygen species (Gupta et al. 2018). They also participate in the dissipation of excess energy and help to stabilize photosynthetic structures. Additionally, they can also act as signaling molecules that have a positive impact on plant response to nutritional stress (Gupta et al. 2018).

We observed a gender-based effect on $\mathrm{H}_{2} \mathrm{O}_{2}$ content in $J$. communis needles. In Populus cathayana $\mathrm{N}$ - and P-deficient females had higher levels of $\mathrm{H}_{2} \mathrm{O}_{2}$ as they showed lower peroxidase activity (Zhang et al. 2014). Similarly, we observed a higher level of $\mathrm{H}_{2} \mathrm{O}_{2}$ in females in the first year, but during the second year, it was higher in males. A higher level of $\mathrm{H}_{2} \mathrm{O}_{2}$ was also connected with male's lower activity of APX. Similarly, in studies by Zhang et al. (2010), females showed lower ROS levels, which were additionally connected with stress conditions. On the other hand, we did not trace the differences between genders in $\mathrm{O}_{2}^{-}$. As we observed, $\mathrm{SOD}$ and CAT activities were higher in males in the first year during the time of slower metabolic processes and stresses connected with cold and low light intensity. It might indicate on males' better performance during cold stress and stay in opposition to findings of Gupta et al. (2012) where females showed higher SOD activity as a response to cold stress. In our studies, SOD activity was higher in females during flowering, which can indicate males' reproductive effort connected with pollen production, which may be very resource consuming in wind-pollinated species (Teitel et al. 2016).

Differences between fertilized and non-fertilized individuals of J. communis depended on the season, which is in agreement with other reports demonstrating seasonal differences in plant response to environmental conditions (Troeng and Linder 1982; Lewis et al. 1996; Nowak-Dyjeta et al. 2017; Wang et al. 2018). In the current study, nutrient availability (fertilized vs. non-fertilized) affected a wide range of metabolic processes. Almost all of the measured parameters including photosynthetic capacity assessed as ETR $_{\max }$, were lower in needles of non-fertilized plants than in needles of fertilized plants during at least one measuring term. A similar experiment conducted on Taxus baccata revealed that non-fertilized plants were more sensitive to photoinhibition than fertilized (Robakowski et al. 2018). A stronger 
photoinhibitory stress response in non-fertilized $T$. baccata plants was evidenced as lower $F_{\mathrm{v}} / F_{\mathrm{m}}, \mathrm{ETR}_{\text {max }}$, and $\Phi_{\mathrm{PPF}_{\mathrm{sat}}}$ values, as well as a lower concentration of photosynthetic pigments and higher NPQ values (Robakowski et al. 2018). These parameters exhibited similar differences in response to nutrient availability (fertilized vs. non-fertilized conditions) in J. communis as they did in T. baccata, except for $\Phi_{\mathrm{PPF}_{\text {sat }}}$ which was higher in non-fertilized plants within most measuring terms, when differences were significant. These findings are in accordance with other reports of nutrition limitation as a significant factor impacting photosynthetic efficiency (Lima et al. 1999; Starck et al. 2000; Zhao et al. 2018). A negligible effect of nutrient availability, however, has also been reported (Klooster et al. 2010; Msanne et al. 2017). In response to mineral starvation, plants exhibit a down-regulation of genes connected to photosynthesis ( $\mathrm{Wu}$ et al. 2003) and can be more vulnerable to photoinhibition (Simancas et al. 2016). In contrast to the results of Simancas et al. (2016) and Zhao et al. (2018), and similar to the study in T. baccata (Robakowski et al. 2018), results of the current $J$. communis study indicate that nutrient supplementation increases the capacity of this woody plant to cope with stresses, due to the constitutive expression of higher antioxidant enzyme (SOD, POX, and CAT) activity, higher levels of carotenoids, and a lower formation of free radicals.

\section{Conclusions}

Our results indicate that needles in male and female plants of $J$. communis differ in photosynthetic efficiency, level of ROS formation, and antioxidant enzymes' activity. The differences were observed regardless of nutrient availability. Females have lower photosynthetic capacity than males, lower concentration of chlorophyll per unit dry mass, and lower leaf absorbed energy loss. Differences between males and females in photosynthetic efficiency appeared during the most intensive growth and flowering indicating that males increase energy gain and losses when they invest more resources into reproduction. Males showed higher values of ROS, and differences between sexes in enzymes' activities were dependent on enzyme and season. Males showed a higher concentration of carotenoids per unit dry mass, which shows that genders of $J$. communis have different adaptations to cope with stressors. The results of our study indicate that most of the gender-based differences in J. communis are genetically based constitutive traits and are characteristic for each sex, as they appear independently of nutrient supplementation.

\section{Author contribution statement}

Study conception and design: EPK, GI, and MR; acquisition of data: MR, ER, and RZ; analysis and interpretation of data MR, PR, and EPK; drafting of first version of the manuscript: MR and final version: MR, PR, EPK, ER, GI, and RŻ.

Acknowledgments The authors would like to thank Stanisław Zymon and Kinga Nowak for help during rooting shoots and the fieldwork.

Funding This project was financed by the Polish National Science Centre [grant number 2015/19/N/NZ8/03850] and co-financed by statutory research of the Institute of Dendrology, Polish Academy of Sciences.

\section{Compliance with ethical standards}

Conflict of interest The authors declare that the research was conducted in the absence of any personal, professional or financial relationships that could potentially be construed as a conflict of interest.

Open Access This article is licensed under a Creative Commons Attribution 4.0 International License, which permits use, sharing, adaptation, distribution and reproduction in any medium or format, as long as you give appropriate credit to the original author(s) and the source, provide a link to the Creative Commons licence, and indicate if changes were made. The images or other third party material in this article are included in the article's Creative Commons licence, unless indicated otherwise in a credit line to the material. If material is not included in the article's Creative Commons licence and your intended use is not permitted by statutory regulation or exceeds the permitted use, you will need to obtain permission directly from the copyright holder. To view a copy of this licence, visit http://creativecommons.org/licenses/by/4.0/.

\section{References}

Adams WW, Winter K, Schreiber U, Schramel P (1990) Photosynthesis and chlorophyll fluorescence characteristics in relationship to changes in pigment and element composition of leaves of Platanus occidentalis L. during autumnal leaf senescence. Plant Physiol 92:1184-1190

Adams RP, Pandey RN, Leverenz JW, Dignard N, Hoegh K, Thorfinnsson T (2003) Pan-arctic variation in Juniperus communis: historical biogeography based on DNA fingerprinting. Biochem Syst Ecol 31:181-192. https://doi.org/10.1016/S0305-1978(02)00091 $-1$

Adams WW, Zarter CR, Ebbert V, Demmig-Adams B (2004) Photoprotective strategies of overwintering evergreens. Bioscience 54:4149. https://doi.org/10.1641/0006-3568(2004)054[0041:PSOOE 12.0.CO;2

Ait Said S, Torre F, Derridj A, Gauquelin T, Mevy JP (2013) Gender, mediterranean drought, and seasonality: photosystem II photochemistry in Pistacia lentiscus L. Photosynthetica 51:552-564. https://doi.org/10.1007/s11099-013-0055-9

Alguacil M, Caravaca F, Díaz-Vivancos P, Hernández JA, Roldán A (2006) Effect of arbuscular mycorrhizae and induced drought stress on antioxidant enzyme and nitrate reductase activities in Juniperus oxycedrus L. grown in a composted sewage sludge-amended semi-arid soil. Plant Soil 279:209. https://doi. org/10.1007/s11104-005-1238-3 
Allen GA, Antos JA (1993) Sex ratio variation in the dioecious shrub Oemleria cerasiformis. Am Nat 141:537-553

Barnes JD, Balaguer L, Manrique E, Elvira S, Davison AW (1992) A reappraisal of the use of DMSO for the extraction and determination of chlorophylls $\mathrm{a}$ and $\mathrm{b}$ in lichens and higher plants. Environ Exp Bot 32:85-100. https://doi.org/10.1016/00988472(92)90034-Y

Barradas MCD, Correia O (1999) Sexual dimorphism, sex ratio and spatial distribution of male and female shrubs in the dioecious species Pistacia lentiscus L. Folia Geobot 34:163-174. https:// doi.org/10.1007/BF02803082

Björkman O, Demmig B (1987) Photon yield of $\mathrm{O}_{2}$ evolution and chlorophyll fluorescence characteristics at $77 \mathrm{~K}$ among vascular plants of diverse origins. Planta 170:489-504

Bradford MM (1976) A rapid and sensitive method for the quantitation of microgram quantities of protein utilizing the principle of protein-dye binding. Anal Biochem 72:248-254. https://doi. org/10.1016/0003-2697(76)90527-3

Chance B, Maehly AC (1955) Assay of catalases and peroxidases. Methods Enzymol 2:764-775. https://doi.org/10.1016/S0076 $-6879(55) 02300-8$

Chen J, Duan B, Wang M, Korpelainen H, Li C (2014) Intra- and inter-sexual competition of Populus cathayana under different watering regimes. Funct Ecol 28:124-136. https://doi. org/10.1111/1365-2435.12180

Chen J, Dong T, Duan B, Korpelainen H, Niinemets Ü, Li C (2015) Sexual competition and N supply interactively affect the dimorphism and competiveness of opposite sexes in Populus cathayana. Plant Cell Environ 38:1285-1298. https://doi.org/10.1111/ pce. 12477

Correia O, Diaz Barradas MC (2000) Ecophysiological differences between male and female plants of Pistacia lentiscus L. Plant Ecol 149:131-142

Croft H, Chen JM, Luo X, Bartlett P, Chen B, Staebler RM (2017) Leaf chlorophyll content as a proxy for leaf photosynthetic capacity. Glob Change Biol 23:3513-3524. https://doi. org/10.1111/gcb.13599

Dawson TE, Bliss LC (1989) Patterns of water use and the tissue water relations in the dioecious shrub, Salix arctica: the physiological basis for habitat partitioning between the sexes. Oecologia 79:332-343. https://doi.org/10.1007/BF00384312

de Bandera del la MC, Traveset A, Valladares F, Gulías J (2008) Gender, season and habitat: patterns of variation in photosynthetic activity, growth and fecundity in Thymelaea velutina. Acta Oecologica 34:294-302. https://doi.org/10.1016/j.actao .2008.06.002

Delph LF, Andicoechea J, Steven JC, Herlihy CR, Scarpino SV, Bell DL (2011) Environment-dependent intralocus sexual conflict in a dioecious plant. New Phytol 192:542-552. https://doi.org/10. 1111/j.1469-8137.2011.03811.x

Doke N (1983) Generation of superoxide anion by potato tuber protoplasts during the hypersensitive response to hyphal wall components of Phytophthora infestans and specific inhibition of the reaction by suppressors of hypersensitivity. Physiol Plant Pathol 23:359-367. https://doi.org/10.1016/0048-4059(83)90020-6

Evans JR (1993) Photosynthetic acclimation and nitrogen partitioning within a lucerne canopy, II. Stability through time and comparison with a theoretical optimum. Aust J Plant Physiol 20:69-82

Field DL, Pickup M, Barrett SCH (2013) Comparative analyses of sex-ratio variation in dioecious flowering plants. Evolution 67:661-672. https://doi.org/10.1111/evo.12001

Foyer $\mathrm{CH}$ (2018) Reactive oxygen species, oxidative signaling and the regulation of photosynthesis. Environ Exp Bot 154:134-142. https://doi.org/10.1016/j.envexpbot.2018.05.003
Foyer CH, Shigeoka S (2011) Understanding oxidative stress and antioxidant functions to enhance photosynthesis. Plant Physiol 155:93-100. https://doi.org/10.1104/pp.110.166181

Freeman DC, Klikoff LG, Harper KT (1976) Differential resource utilization by the sexes of dioecious plants. Science 193:597-599. https://doi.org/10.1126/science.193.4253.597

Geber MA, Dawson TE, Delph LF (1999) Gender and sexual dimorphism in flowering plants. Springer, Berlin, Heidelberg

Gehring JL, Monson RK (1994) Sexual differences in gas exchange and response to environmental stress in dioecious Silene latifolia (Caryophyllaceae). Am J Bot 81:166-174

Genty B, Briantais JM, Baker NR (1989) The relationship between the quantum yield of photosynthetic electron transport and quenching of chlorophyll fluorescence. Biochim Biophys Acta Gen Subj 990:87-92

Giannopolitis CN, Ries SK (1977) Superoxide dismutases: I. Occurrence in higher plants. Plant Physiol 59:309-314

Givnish TJ (1988) Adaptation to sun and shade: a whole-plant perspective. Aust J Plant Physiol 15:63-92

Gupta SM, Grover A, Pandey P, Ahmed Z (2012) Female plants of Hippophae salicifolia D. Don are more responsive to cold stress than male plants. Physiol Mol Biol Plants 18:377-380. https:// doi.org/10.1007/s12298-012-0133-7

Gupta DK, Palma JM, Corpas FJ (2018) Antioxidants and antioxidant enzymes in higher plants. Springer International Publishing, Berlin

Güsewell S, Bollens U (2003) Composition of plant species mixtures grown at various $\mathrm{N}: \mathrm{P}$ ratios and levels of nutrient supply. Basic Appl Ecol 4:453-466. https://doi.org/10.1078/1439-1791-00174

Güsewell S, Koerselman W (2002) Variation in nitrogen and phosphorus concentrations of wetland plants. Perspect Plant Ecol Evol Syst 5:37-61. https://doi.org/10.1078/1433-8319-0000022

He M, Shi D, Wei X, Hu Y, Wang T, Xie Y (2016) Gender-related differences in adaptability to drought stress in the dioecious tree Ginkgo biloba. Acta Physiol Plant 38:124. https://doi. org/10.1007/s11738-016-2148-0

Helmerhorst E, Stokes GB (1980) Microcentrifuge desalting: a rapid, quantitative method for desalting small amounts of protein. Anal Biochem 104:130-135

Hermans C, Hammond JP, White PJ, Verbruggen N (2006) How do plants respond to nutrient shortage by biomass allocation? Trends Plant Sci 11:610-617. https://doi.org/10.1016/j.tplan ts.2006.10.007

Holopainen JK, Gershenzon J (2010) Multiple stress factors and the emission of plant VOCs. Trends Plant Sci 15:176-184. https:// doi.org/10.1016/j.tplants.2010.01.006(special issue: induced biogenic volatile organic compounds from plants)

Huang K, Liao Y, Dong T, Yang Y, He J, Huan H, Zhang Q, Xu X (2018) Sex-specific responses of tree-ring growth to climate in the dioecious tree Populus cathayana. J Plant Ecol 11:771-779. https://doi.org/10.1093/jpe/rtx048

Hultine KR, Grady KC, Wood TE, Shuster SM, Stella JC, Whitham TG (2016) Climate change perils for dioecious plant species. Nat Plants 2:16109. https://doi.org/10.1038/nplants.2016.109

Iszkuło G, Boratyński A (2011) Initial period of sexual maturity determines the greater growth rate of male over female in the dioecious tree Juniperus communis subsp. communis. Acta Oecologica 37:99-102. https://doi.org/10.1016/j.actao.2011.01.001

Iszkuło G, Jasińska AK, Giertych MJ, Boratyński A (2009) Do secondary sexual dimorphism and female intolerance to drought influence the sex ratio and extinction risk of Taxus baccata? Plant Ecol 200:229-240. https://doi.org/10.1007/s11258-008-9447-5

Iszkuło G, Kosiński P, Hajnos M (2013) Sex influences the taxanes content in Taxus baccata. Acta Physiol Plant 35:147-152. https ://doi.org/10.1007/s11738-012-1057-0 
Jiang H, Zhang S, Lei Y, Xu G, Zhang D (2016) Alternative growth and defensive strategies reveal potential and gender specific trade-offs in dioecious plants Salix paraplesia to nutrient availability. Front Plant Sci 7:1064. https://doi.org/10.3389/fpls.2016.01064

Klooster WS, Cregg BM, Fernandez RT, Nzokou P (2010) Growth and photosynthetic response of pot-in-pot-grown conifers to substrate and controlled-release fertilizer. Hort Sci 45:36-42. https://doi. org/10.21273/HORTSCI.45.1.36

Kohorn LU (1994) Shoot morphology and reproduction in Jojoba: advantages of sexual dimorphism. Ecology 75:2384-2394. https ://doi.org/10.2307/1940892

Kromdijk J, Głowacka K, Leonelli L, Gabilly ST, Iwai M, Niyogi KK, Long SP (2016) Improving photosynthesis and crop productivity by accelerating recovery from photoprotection. Science $354: 857-$ 861. https://doi.org/10.1126/science.aai8878

Kutbay HG, Ok T (2003) Foliar N and P resorption and nutrient levels along an elevational gradient in Juniperus oxycedrus L. subsp. macrocarpa (Sibth. \& Sm.) Ball. Ann For Sci 60:449-454. https ://doi.org/10.1051/forest:2003037

Laliberté E, Shipley B, Norton DA, Scott D (2012) Which plant traits determine abundance under long-term shifts in soil resource availability and grazing intensity? J Ecol 100:662-677. https:// doi.org/10.1111/j.1365-2745.2011.01947.x

Laporte MM, Delph LF (1996) Sex-specific physiology and sourcesink relations in the dioecious plant Silene latifolia. Oecologia 106:63-72. https://doi.org/10.1007/BF00334408

Lei Y, Chen K, Jiang H, Yu L, Duan B (2017a) Contrasting responses in the growth and energy utilization properties of sympatric Populus and Salix to different altitudes: implications for sexual dimorphism in Salicaceae. Physiol Plant 159:30-41. https://doi. org/10.1111/ppl.12479

Lei Y, Jiang Y, Chen K, Duan B, Zhang S, Korpelainen H, Niinemets U, Li C (2017b) Reproductive investments driven by sex and altitude in sympatric Populus and Salix trees. Tree Physiol 37:1503-1514. https://doi.org/10.1093/treephys/tpx075

Leigh A, Nicotra AB (2003) Sexual dimorphism in reproductive allocation and water use efficiency in Maireana pyramidata (Chenopodiaceae), a dioecious, semi-arid shrub. Aust J Bot 51:509-514. https://doi.org/10.1071/bt03043

Lewis JD, Tissue DT, Strain BR (1996) Seasonal response of photosynthesis to elevated $\mathrm{CO}_{2}$ in loblolly pine (Pinus taeda $\mathrm{L}$.) over two growing seasons. Glob Change Biol 2:103-114. https://doi. org/10.1111/j.1365-2486.1996.tb00055.x

Li Y, He N, Hou J, Xu L, Liu C, Zhang J, Wang Q, Zhang X, Wu X (2018) Factors influencing leaf chlorophyll content in natural forests at the biome scale. Front Ecol Evol 6:1-10. https://doi. org/10.3389/fevo.2018.00064

Liao J, Song H, Tang D, Zhang S (2019) Sexually differential tolerance to water deficiency of Salix paraplesia-a female-biased alpine willow. Ecol Evol 9:8450-8464. https://doi.org/10.1002/ ece3.5175

Lima JD, Mosquim PR, Da Matta FM (1999) Leaf gas exchange and chlorophyll fluorescence parameters in Phaseolus vulgaris as affected by nitrogen and phosphorus deficiency. Photosynthetica 37:113-121. https://doi.org/10.1023/A:1007079215683

Lloyd DG, Webb CJ (1977) Secondary sex characters in plants. Bot Rev 43:177-216. https://doi.org/10.1007/BF02860717

Lu Y, Wang G, Meng Q, Zhang W, Duan B (2014) Growth and physiological responses to arbuscular mycorrhizal fungi and salt stress in dioecious plant Populus tomentosa. Can J For Res 44:10201031. https://doi.org/10.1139/cjfr-2014-0009

Lüttge U, Berg A, Fetene M, Nauke P, Peter D, Beck E (2003) Comparative characterization of photosynthetic performance and water relations of native trees and exotic plantation trees in an
Ethiopian forest. Trees 17:40-50. https://doi.org/10.1007/s0046 8-002-0201-7

Maxwell K, Johnson GN (2000) Chlorophyll fluorescence-a practical guide. J Exp Bot 51:659-668. https://doi.org/10.1093/jexbo $\mathrm{t} / 51.345 .659$

Meagher TR (1999) The quantitative genetics of sexual dimorphism. In: Geber MA, Dawson TE, Delph LF (eds) Gender and sexual dimorphism in flowering plants. Springer, Berlin, pp 275-294. https://doi.org/10.1007/978-3-662-03908-3_10

Messier C, Puttonen P (1995) Spatial and temporal variation in the light environment of developing Scots pine stands: the basis for a quick and efficient method of characterizing light. Can J For Res 25:343-354

Miller PM, Eddleman LE, Kramer S (1990) Allocation patterns of carbon and minerals in juvenile and small-adult Juniperus occidentalis. For Sci 36:734-747. https://doi.org/10.1093/forestscie nce/36.3.734

Mitchell AK (1998) Acclimation of Pacific yew (Taxus brevifolia) foliage to sun and shade. Tree Physiol 18:749-757. https://doi. org/10.1093/treephys/18.11.749

Montesinos D, De Luis M, Verdú M, Raventos J, Garcia-Fayos P (2006) When, how and how much: gender-specific resourceuse strategies in the dioecious tree Juniperus thurifera. Ann Bot 98:885-889. https://doi.org/10.1093/aob/mcl172

Montesinos D, Villar-Salvador P, García-Fayos P, Verdú M (2012) Genders in Juniperus thurifera have different functional responses to variations in nutrient availability. New Phytol 193:705-712. https ://doi.org/10.1111/j.1469-8137.2011.03982.x

Msanne J, Awada T, Bryan NM, Schacht W, Drijber R, Li Y, Zhou X, Okalebo J, Wedin D, Brandle J, Hiller J (2017) Ecophysiological responses of native invasive woody Juniperus virginiana $\mathrm{L}$. to resource availability and stand characteristics in the semiarid grasslands of the Nebraska Sandhills. Photosynthetica 55:219230. https://doi.org/10.1007/s11099-016-0683-y

Nakano Y, Asada K (1981) Hydrogen peroxide in scavenged by ascorbate-specific peroxidase in spinach chloroplasts. Plant Cell Physiol 22:867-880. https://doi.org/10.1093/oxfordjournals.pcp. a076232

Nicotra AB, Chazdon RL, Montgomery RA (2003) Sexes show contrasting patterns of leaf and crown carbon gain in a dioecious rainforest shrub. Am J Bot 90:347-355. https://doi.org/10.3732/ ajb.90.3.347

Nowak-Dyjeta K, Giertych MJ, Thomas P, Iszkuło G (2017) Males and females of Juniperus communis L. and Taxus baccata L. show different seasonal patterns of nitrogen and carbon content in needles. Acta Physiol Plant 39:191. https://doi.org/10.1007/ s11738-017-2489-3

Obeso JR (2002) The costs of reproduction in plants. New Phytol 155:321-348. https://doi.org/10.1046/j.1469-8137.2002.00477.x

Obeso JR, Alvarez-Santullano M, Retuerto R (1998) Sex ratios, size distributions, and sexual dimorphism in the dioecious tree Ilex aquifolium (Aquifoliaceae). Am J Bot 85:1602-1608. https://doi. org/10.2307/2446488

Oostermeijer JGB, De Knegt B (2004) Genetic population structure of the wind-pollinated, dioecious shrub Juniperus communis in fragmented Dutch heathlands. Plant Species Biol 19:175-184. https://doi.org/10.1111/j.1442-1984.2004.00113.x

Ortiz PL, Arista M, Talavera S (2002) Sex ratio and reproductive effort in the dioecious Juniperus communis subsp. alpina (Suter) Čelak. (Cupressaceae) along an altitudinal gradient. Ann Bot 89:205-211. https://doi.org/10.1093/aob/mcf028

Pozo JCD, Allona I, Rubio V, Leyva A, Peña ADL, Aragoncillo C, PazAres J (1999) A type 5 acid phosphatase gene from Arabidopsis thaliana is induced by phosphate starvation and by some other 
types of phosphate mobilising/oxidative stress conditions. Plant $\mathbf{J}$ 19:579-589. https://doi.org/10.1046/j.1365-313X.1999.00562.x

Pukacka S, Pukacki PM (2000) Seasonal changes in antioxidant level of Scots pine (Pinus sylvestris L.) needles exposed to industrial pollution. II. Enzymatic scavengers activities. Acta Physiol Plant 22:457-464. https://doi.org/10.1007/s11738-000-0089-Z

Qin F, Liu G, Huang G, Dong T, Liao Y, Xu X (2018) Zinc application alleviates the adverse effects of lead stress more in female Morus alba than in males. Environ Exp Bot 146:68-76. https:// doi.org/10.1016/j.envexpbot.2017.10.003

Rascher U, Liebig M, Lüttge U (2000) Evaluation of instant lightresponse curves of chlorophyll fluorescence parameters obtained with a portable chlorophyll fluorometer on site in the field. Plant Cell Environ 23:1397-1405. https://doi.org/10.104 6/j.1365-3040.2000.00650.x

R Core Team (2018) R: A Language and environment for statistical computing. R Foundation for Statistical Computing, Vienna, Austria. https://www.R-project.org/. Accessed 08 Nov 2019

Ren J, Duan B, Zhang X, Korpelainen H, Li C (2010) Differences in growth and physiological traits of two poplars originating from different altitudes as affected by UV-B radiation and nutrient availability. Physiol Plant 138:278-288. https://doi.org/10.111 1/j.1399-3054.2009.01328.x

Retuerto R, Fernández-Lema B, Obeso JR (2006) Changes in photochemical efficiency in response to herbivory and experimental defoliation in the dioecious tree Ilex aquifolium. Int J Plant Sci 167:279-289. https://doi.org/10.1086/498919

Robakowski P (2005) Susceptibility to low-temperature photoinhibition in three conifers differing in successional status. Tree Physiol 25:1151-1160. https://doi.org/10.1093/treephys/25.9.1151

Robakowski P, Pers-Kamczyc E, Ratajczak E, Thomas PA, Ye Z-P, Rabska M, Iszkuło G (2018) Photochemistry and antioxidative capacity of female and male Taxus baccata L. acclimated to different nutritional environments. Front Plant Sci 9:742. https:// doi.org/10.3389/fpls.2018.00742

Rocheleau AF, Houle G (2001) Different cost of reproduction for the males and females of the rare dioecious shrub Corema conradii (Empetraceae). Am J Bot 88:659-666. https://www.jstor.org/ stable/2657066

Rouached H, Arpat AB, Poirier Y (2010) Regulation of phosphate starvation responses in plants: signaling players and cross-talks. Mol Plant 3:288-299. https://doi.org/10.1093/mp/ssp120

Sagisaka S (1976) The occurrence of peroxide in a perennial plant, Populus gelrica. Plant Physiol 57:308-309

Sanderson BJ, Wang L, Tiffin P, Wu Z, Olson MS (2019) Sex-biased gene expression in flowers, but not leaves, reveals secondary sexual dimorphism in Populus balsamifera. New Phytol 221:527539. https://doi.org/10.1111/nph.15421

Sardans J, Rivas-Ubach A, Peñuelas J (2012) The C:N:P stoichiometry of organisms and ecosystems in a changing world: a review and perspectives. Perspect Plant Ecol Evol Syst 14:33-47. https://doi. org/10.1016/j.ppees.2011.08.002

Schmidt SR, Kleinebecker T, Vogel A, Hölzel N (2010) Interspecific and geographical differences of plant tissue nutrient concentrations along an environmental gradient in Southern Patagonia. Chile Aquat Bot 92:149-156. https://doi.org/10.1016/j.aquab ot.2009.11.002

Simancas B, Juvany M, Cotado A, Munné-Bosch S (2016) Sex-related differences in photoinhibition, photo-oxidative stress and photoprotection in stinging nettle (Urtica dioica $\mathrm{L}$.) exposed to drought and nutrient deficiency. J Photochem Photobiol B 156:22-28. https://doi.org/10.1016/j.jphotobiol.2016.01.005

Song H, Lei Y, Zhang S (2018) Differences in resistance to nitrogen and phosphorus deficiencies explain male-biased populations of poplar in nutrient-deficient habitats. J Proteomics 178:123-127. https://doi.org/10.1016/j.jprot.2017.11.013
Starck Z, Niemyska B, Bogdan J, Akour Tawalbeh RN (2000) Response of tomato plants to chilling stress in association with nutrient or phosphorus starvation. Plant Soil 226:99-106. https://doi. org/10.1023/A:1026497104077

Szabó I, Bergantino E, Giacometti GM (2005) Light and oxygenic photosynthesis: energy dissipation as a protection mechanism against photo-oxidation. EMBO Rep 6:629-634. https://doi.org/10.1038/ sj.embor.7400460

Teitel Z, Pickup M, Field DL, Barrett SCH (2016) The dynamics of resource allocation and costs of reproduction in a sexually dimorphic, wind-pollinated dioecious plant. Plant Biol 18:98-103. https://doi.org/10.1111/plb.12336

Tewari RK, Kumar P, Sharma PN (2007) Oxidative stress and antioxidant responses in young leaves of Mulberry plants grown under nitrogen, phosphorus or potassium deficiency. J Integr Plant Biol 49:313-322. https://doi.org/10.1111/j.1744-7909.2007.00358.x

Thomas PA, El-Barghathi M, Polwart A (2007) Biological flora of the British Isles: Juniperus communis L. J Ecol 95:1404-1440. https ://doi.org/10.1111/j.1365-2745.2007.01308.x

Troeng E, Linder S (1982) Gas exchange in a 20-year-old stand of Scots pine. Physiol Plant 54:7-14. https://doi. org/10.1111/j.1399-3054.1982.tb00569.x

Verheyen K, Adriaenssens S, Gruwez R, Michalczyk IM, Ward LK, Rosseel Y, den Broeck AV, García D (2009) Juniperus communis: victim of the combined action of climate warming and nitrogen deposition? Plant Biol 11:49-59. https://doi.org/10.11 11/j.1438-8677.2009.00214.x

Wallace CS, Rundel PW (1979) Sexual dimorphism and resource allocation in male and female shrubs of Simmondsia chinensis. Oecologia 44:34-39. https://doi.org/10.1007/BF00346394

Wang X, Ciais P, Wang Y, Zhu D (2018) Divergent response of seasonally dry tropical vegetation to climatic variations in dry and wet seasons. Glob Change Biol 24:4709-4717. https://doi. org/10.1111/gcb.14335

Wu P, Ma L, Hou X, Wang M, Wu Y, Liu F, Deng XW (2003) Phosphate starvation triggers distinct alterations of genome expression in Arabidopsis roots and leaves. Plant Physiol 132:12601271. https://doi.org/10.1104/pp.103.021022

Xu X, Peng G, Wu C, Korpelainen H, Li C (2008) Drought inhibits photosynthetic capacity more in females than in males of Populus cathayana. Tree Physiol 28:1751-1759. https://doi.org/10.1093/ treephys/28.11.1751

Ye Z-P, Robakowski P, Suggett DJ (2013) A mechanistic model for the light response of photosynthetic electron transport rate based on light harvesting properties of photosynthetic pigment molecules. Planta 237:837-847. https://doi.org/10.1007/s00425-012-1790-z

Zhang S, Lu S, Xu X, Korpelainen H, Li C (2010) Changes in antioxidant enzyme activities and isozyme profiles in leaves of male and female Populus cathayana infected with Melampsora laricipopulina. Tree Physiol 30:116-128. https://doi.org/10.1093/treep hys/tpp094

Zhang S, Jiang H, Zhao H, Korpelainen H, Li C (2014) Sexually different physiological responses of Populus cathayana to nitrogen and phosphorus deficiencies. Tree Physiol 34:343-354. https:// doi.org/10.1093/treephys/tpu025

Zhang Y, Feng L, Jiang H, Zhang Y, Zhang S (2017) Different proteome profiles between male and female Populus cathayana exposed to UV-B radiation. Front Plant Sci 8:320. https://doi. org/10.3389/fpls.2017.00320

Zhao H, Zhang S, Li J, Song M, Pang J (2018) Effects of $\mathrm{NH}_{4}^{-}$and $\mathrm{NO}_{3}^{-}$ on sexual dimorphism responses to manganese stress in a dioecious tree species. Trees 32:473-488. https://doi.org/10.1007/ s00468-017-1644-1

Publisher's Note Springer Nature remains neutral with regard to jurisdictional claims in published maps and institutional affiliations. 


\title{
Affiliations
}

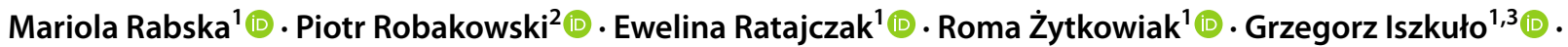
Emilia Pers-Kamczyc ${ }^{1}$ (D)

\author{
Mariola Rabska \\ mrabska@man.poznan.pl \\ Piotr Robakowski \\ pierrot@up.poznan.pl \\ Ewelina Ratajczak \\ eratajcz@man.poznan.pl \\ Roma Żytkowiak \\ romazyt@man.poznan.pl \\ Grzegorz Iszkuło \\ iszkulo@man.poznan.pl
}

1 Institute of Dendrology, Polish Academy of Sciences, Parkowa 5, 62-035 Kornik, Poland

2 Department of Silviculture, Faculty of Forestry, Poznań University of Life Sciences, Poznan, Poland

3 Faculty of Biological Sciences, University of Zielona Góra, Zielona Gora, Poland 